\title{
Information overload in the information age: a review of the literature from business administration, business psychology, and related disciplines with a bibliometric approach and framework development
}

\author{
Peter Gordon Roetzel ${ }^{1,2}$
}

Received: 23 May 2017/ Accepted: 25 June 2018/Published online: 6 July 2018

(C) The Author(s) 2018

\begin{abstract}
In the light of the information age, information overload research in new areas (e.g., social media, virtual collaboration) rises rapidly in many fields of research in business administration with a variety of methods and subjects. This review article analyzes the development of information overload literature in business administration and related interdisciplinary fields and provides a comprehensive and overarching overview using a bibliometric literature analysis combined with a snowball sampling approach. For the last decade, this article reveals research directions and bridges of literature in a wide range of fields of business administration (e.g., accounting, finance, health management, human resources, innovation management, international management, information systems, marketing, manufacturing, or organizational science). This review article identifies the major papers of various research streams to capture the pulse of the information overload-related research and suggest new questions that could be addressed in the future and identifies concrete open gaps for further research. Furthermore, this article presents a new framework for structuring information overload issues which extends our understanding of influence factors and effects of information overload in the decision-making process.
\end{abstract}

Keywords Information processing - Information management strategies · Information overload $\cdot$ Literature review $\cdot$ Bibliometric literature analysis

Peter Gordon Roetzel

peter.roetzel@bwi.uni-stuttgart.de

1 University of Stuttgart, Keplerstr. 17, 70174 Stuttgart, Germany

2 University of Applied Sciences Aschaffenburg, Aschaffenburg, Germany 


\section{Introduction}

Information overload is a decisive factor driving negative "work environments [that] are killing productivity, dampening creativity, and making us unhappy" (Dean and Webb 2011). Losses arising directly or indirectly from information overload are estimated at $\$ 650$ billion worldwide each year (Lohr 2007) - an amount that equals the gross domestic product of Switzerland in 2015 (United Nations Statistic Division 2016).

Information overload occurs when decision-makers face a level of information that is greater than their information processing capacity, i.e., an overly high information load (Schroder et al. 1967; Eppler and Mengis 2004), but the phenomenon is not confined to the modern world. As Blair (2012) noted in her review article, even in the thirteenth century, scholars complained of "the key ingredients of the feeling of overload which are still with us today: "the multitude of books, the shortness of time and the slipperiness of memory" (Blair 2012, p. 1). Two radical innovations supported the rapid increase in the availability of information and the decrease in information search-related costs: Gutenberg's printing innovations and the rise of information technology (IT). Before these radical innovations, the issue of information overload was limited to a wealthy and privileged elite. In particular, the rise of IT and the use of internet services have resulted in an expansion of information overload-related problems for all social ranks. In ancient and medieval times, the nobility and academics almost exclusively faced information overload-related problems, as Blair (2012) and Levitin (2014) suggested.

Information (over-)load research peaked in the 1980s and 1990s; interest in this topic quieted down in the 2000s (Eppler and Mengis 2004; Ding and Beaulieu 2011; Lewis 1996; Edmunds and Morris 2000; Feather 1988) and languished in the 2010s. In retrospect, research found many impacts and implications of information load and developed countermeasures. However, a quarter century after interest in information load research peaked, the information load of managers in day-to-day operations has quadrupled. Thus, in the information age, information overload research in new areas (e.g., social media, virtual collaboration) seems to be rising rapidly (Dean and Webb 2011; Hemp 2009; Kolfschoten and Brazier 2013; Shapiro and Varian 2013).

But since the often-cited literature review of Eppler and Mengis (2004), ${ }^{1}$ no study has yet focused on offering a comprehensive and overarching literature review regarding information overload. The prior literature offers some discipline-specific literature reviews, which allow in-depth insights and an understanding of information overload in each discipline: marketing and organizational science (Klausegger et al. 2007), healthcare management (Hall and Walton 2004), business informatics conferences (Melinat et al. 2014), technology-based education (Shrivastav and Hiltz 2013), general management (Jackson and Farzaneh 2012), and business-related psychotherapy (Case et al. 2005). But an actual review of information overload in today's information age is still missing.

\footnotetext{
${ }^{1}$ Google Scholar: 1302 cites [1.5.2018].
} 
This literature review aims to close this gap and present a comprehensive and overarching literature review for 2004-2017. This paper contributes to prior research in four ways. First, this paper presents an actual and comprehensive overview regarding the information overload literature in a wide range of fields of business administration (e.g., accounting, finance, health management, human resources, innovation management, international management, information systems (IS) management, marketing, manufacturing, and organizational science). This overview can be a foundation for research in business administration with a focus on information overload issues. This review addresses a limitation noted by Eppler and Mengis (2004), namely that research focusing on information overload from other perspectives (e.g., psychology, health care, and mass communication) is not addressed adequately. As Webster and Watson (2002) noted, review articles are critical to strengthening research itself. Therefore, this paper also identifies the theoretical basis and the method (e.g., experiment, survey) of the papers to ensure comparability. Second, this paper structures prior studies and identifies some avenues for further research. Third, this paper addresses interdisciplinary papers, links fields of research that remain broadly isolated, and answers the call for research from Eppler and Mengis (2004), who stated that "the overload problem calls for interdisciplinary approaches as many of the open research questions in this field cross traditional disciplinary boundaries" (p. 341). Fourth, this paper provides a new framework for structuring information overload issues and extends our understanding of influence factors and effects of information overload in the decision-making process. This paper develops a thorough framework that spans from the starting situation, to the information search and selection via information processing, to decision-making, and to the ex post consequences of the decision.

The remainder of this paper is organized as follows: In the next section, I provide the theoretical basis for information overload and develop a working definition. The subsequent section presents the methodology, including the literature collection process of the bibliometric analysis and a sample description. The fourth section provides descriptive results of the bibliometric analysis. In the final sections of this paper, I present and discuss our results and draw conclusions.

\section{Working definition of information overload}

A widely used standardized definition of information overload is still missing. Eppler and Mengis (2004) listed seven definitions of information overload in the business research literature. Similar to business research, prior research on information processes suffers from a lack of standardized definitions across different disciplines (Edmunds and Morris 2000; Meadow and Yuan 1997). A necessary starting point for this study is a working definition of information overload. This situation prevails in the 2000s (Hadfi and Ito 2013). Thus, a working definition of information overload is needed.

In information overload situations, a decision-maker faces what Herbert Simon called "a wealth of information [which] creates a poverty of attention and a need to allocate that attention efficiently among the overabundance of information sources 
that might consume it" (Simon 1971, pp. 40-41). While research has been aware of this phenomenon since the 1960s (Eppler and Mengis 2004; Bawden and Robinson 2009), the information age has significantly increased the amount of information available: "The information age is drowning us with an unprecedented deluge of data" (Levitin 2014). Shenk (1997) described this phenomenon as data smog, the "muck and druck of the information age" (Shenk 1997, p. 31). Today, decisionmakers can acquire additional information easily (e.g., via management information systems), and the cost of additional information is very low compared to the cost in the pre-IT age (Levitin 2014; Shapiro and Varian 2013). For example, in pre-IT times, any calculation, evaluation, or determination of key performance indicators (KPI) entailed costs to pay employees to perform these calculations. In addition, the acquisition of further management accounting information or reports took time. Currently, a calculation that required several days in pre-IT times can be performed by a management information system (MIS) within seconds (Levitin 2014).

Although decision support IS and the acquisition of information developed rapidly, the decision-maker's cognitive capacity did not. Simon and Newell (1971) stated that limited short-term or working memory and limited information processing capacity per time unit are two decisive factors explaining why decision-makers cannot incorporate an overly high level of information given limited time. ${ }^{2}$ While pre-IT decision-makers could evaluate the acquired information while further analysis was being pursued, today, additional information is available in a minimum of time. Hence, decision-makers may face situations in which they receive much more information than they are able to evaluate.

All prior approaches to information overload share the fact that a level, or a certain set of information, serves as the final straw. To simplify, I refer to this level or set of information a "point" (in the style of mathematical analysis) because in a function a point is represented by an $X$ (the information level-as the independent variable) and a $Y$ (decision-making performance-as the dependent variable). Considering the simple two-dimensional relationship between the information input as the independent variable (e.g., information load, information provided, information received) and the decision-making performance as the dependent variable, the decision output will improve between zero and the particular point at which the human information processing capacity is reached. Beyond that point, the decisionmaker is being asked to handle more information than possible due to his/her limited information processing capacity. At this level of abstraction, all approaches to information load name this state "information overload". The underlying function that describes the relationship between information input and decision output diverges across the approaches. The prevailing view interprets this relationship as an inverted U curve (Driver and Streufert 1969; Driver et al. 1990; Schroder et al. 1967) (see Fig. 1).

Another approach is to consider information complexity in addition to the amount of information (Bawden and Robinson 2009; Eppler and Mengis 2004). IS

\footnotetext{
2 The limitation of time is a theoretical construct drawing on infinite long-term memory, as Simon and Newell (1971) noted. Extreme examples might exist for managerial decisions in which unlimited time is given, but usually time is a decisive factor in managerial decision-making.
} 


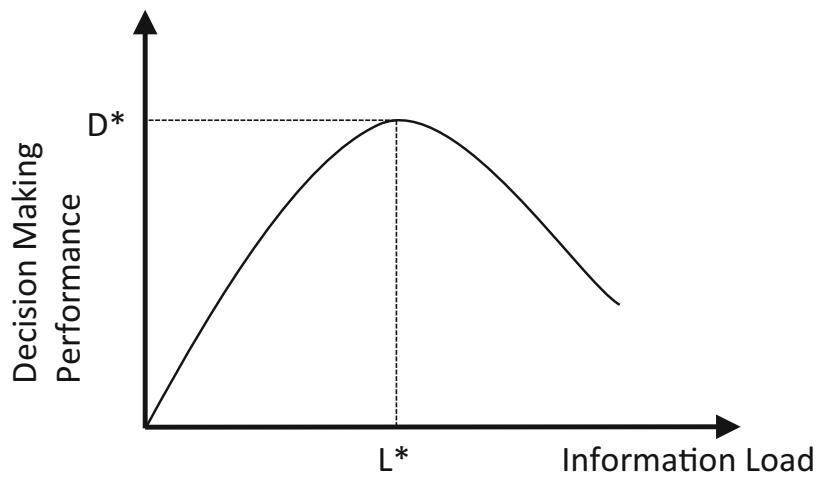

Fig. 1 Information and decision-making performance

research studies address the issue of information complexity with a special focus on information quality (e.g., Doll and Torkzadeh 1988 or Burton-Jones and Straub 2006). If information complexity is high, the decision-maker's information processing capacity might be reached well before the point when only the amount of information is used.

Following this view, at least two possible overarching explanations exist for this turning point (Schroder et al. 1967). First, from a cognitive viewpoint, decisionmakers cannot use more information than his/her limited information processing capacity, stop acquiring information, and make a decision based on the limited information that they have (bounded rationality (Simon 1955)). This sequence assumes that the decision-maker is able to stop information acquisition. However, situations could occur in which stopping would not be possible, e.g., during a meeting.

Second, from an equipment-related viewpoint, the inverted $U$ curve could be explained by limited resources (e.g., time or budget). If a resource that is decisive for decision-making (e.g., time or budget) is limited, the available information cannot be used efficiently. For example, an auditor who is strictly limited for time (to audit) and budget (for size, quality, etc., of his/her auditing team) could face situations where cognitive information processing is not the limitation, but rather his/her resources. Similar situations are imaginable for the context of incomplete contracts.

Limitations stemming from individual characteristics or resources are two sides of the same coin. In situations in which individual characteristics are the decisive driver of information overload, resource limitations might not be reached or could be negligible. By contrast, in situations where resource limitations dominate, individual characteristics might not be reached or may be negligible.

However, the prior literature on information overload focuses on cognitive issues in particular. A relatively recent literature review on information overload by Eppler and Mengis (2004) shows an omission in the research that differentiates between cognition-related and resource-related information overload. Although little research is available on the resource-related issues of information overload, we 
do know that time is a decisive factor in decision-making and that time pressure can decrease decision-making performance due to information overload (Pennington and Tuttle 2007; Schick et al. 1990). However, the modeled time pressure in both experiments (Pennington and Tuttle 2007; Schick et al. 1990) allows decisionmakers to read or analyze all information; thus, they are overwhelmed by the quantity of information. To return to the auditor example, this modeling of time pressure means that the auditor is able to read all expense vouchers, statements of account, etc., but is overwhelmed by the quantity of information. Instead, taking a resource viewpoint, expense vouchers, statements of account, etc., would be so numerous that the auditor (and his or her team) could not read all of them due to limited resources. Research is lacking that models such business situations. Furthermore, the lack of theoretical foundation to unite both business decisionmaking and information processing indicates a theory deficit.

Thus, I use the following working definition of information overload:

Information overload is a state in which a decision maker faces a set of information (i.e., an information load with informational characteristics such as an amount, a complexity, and a level of redundancy, contradiction and inconsistency) comprising the accumulation of individual informational cues of differing size and complexity that inhibit the decision maker's ability to optimally determine the best possible decision. The probability of achieving the best possible decision is defined as decision-making performance. The suboptimal use of information is caused by the limitation of scarce individual resources. A scarce resource can be limited individual characteristics (such as serial processing ability, limited short-term memory) or limited task-related equipment (e.g., time to make a decision, budget).

\section{Methodology}

To investigate the body of literature on information overload, I conducted a bibliometric analysis following the procedure of Schaltegger et al. (2013). The scope of the following literature review on information overload encompasses all business administration studies that deal explicitly with information overload.

Following the procedure of Schaltegger et al. (2013), I started with a snowball sampling (Biernacki and Waldorf 1981). The bibliography on information overload was compiled beginning with the papers identified in Eppler and Mengis (2004). ${ }^{3}$ I did not include working papers, reports, books, and conference proceedings-with one exception: regarding IS research, which highlights conferences, I included peerreviewed papers that were presented at the four major conferences on information

\footnotetext{
3 Eppler and Mengis (2004) reported a methodological limitation: They did not consider relevant articles that addressed information overload situations but used labels other than the four terms "information overload", "information load", "cognitive load", and "cognitive overload". Possible alternative labels might be "data smog, information fatigue/overkill/overabundance/breakdown/explosion/deluge/flood/ stress/plethora, document tsunami, sensory overload" (Eppler and Mengis 2004, p. 329). Using snowball sampling avoids this methodological limitation.
} 
systems (ICIS, ECIS, AMCIS, HICSS). This way, 489 journal articles and 6 IS conference papers were collected. To enlarge the bibliography, I conducted a literature search in four major databases: EBSCO, ProQuest, ScienceDirect and Emerald. Following Eppler and Mengis (2004), I searched for the keywords "information overload", "information load", "cognitive load", and "cognitive overload" with the following conditions: written in English, published after 2004, research articles/papers, peer-reviewed, published in journals. After removing duplicates, 1042 papers were collected in the literature search with the four major databases. Thus, comprehensive data triangulation was achieved by snowball sampling and database query, resulting in a robust bibliographic database with the following characteristics: 1537 research articles/papers in peer-reviewed journals, written by 818 authors, published in 383 academic peer-reviewed journals.

To focus on business administration, I used the VHB-JOURQUAL3 (a ranking of journals relevant to business research based on evaluations by members of the German Academic Association for Business Research) to identify relevant journals. ${ }^{4}$ I excluded papers published in journals that are either not listed in the VHB-JOURQUAL3, are listed in category "D", or are ranked as "k.w.Z." (= "no academic journal"). This procedure resulted in 171 articles ranked in the VHBJOURQUAL3.

To ensure that I did not miss business research-relevant papers, I performed a snowball sampling (Biernacki and Waldorf 1981) with the 171 articles. I found that 39 of these articles are cited in articles published in a peer-reviewed academics journal that do not appear in the VHB-JOURQUAL3: The Elsevier Journal named "Computers in Human Behavior" [CiteScore: 4.54, Impact Factor: 3.435, 5-Year Impact Factor: 4.252, SNIP: 2.137, SCImago Journal Rank (SJR): 1.595]. ${ }^{5}$ Regarding the journal's metrics, this journal can be seen as comparable to other IS journals in the VHB-JOURQUAL3 in category "B" (= important and renowned business research journals). Within the journal "Computers in Human Behavior", I repeated the literature search with the four major databases with the same parameters. I found 138 articles on information overload, but only 18 of these articles are business research-relevant, while the majority of the other articles focus on information overload in pedagogy or general information processing without any business context. I included the 18 articles in the business research-relevant subsample with the 171 articles ranked in the VHB-JOURQUAL3, resulting in 189 articles on information overload.

\footnotetext{
4 In this literature review, I address a limitation noted by Eppler and Mengis (2004), namely that research focusing on information overload from other perspectives (e.g., psychology, health care, and mass communication) is not addressed adequately. As interdisciplinary journals are ranked in the VHBJOURQUAL3, the database includes management-related articles from psychology or health economics and management. Particularly in health economics and management, physicians and patients face a substantial information load in time-critical decision situations. Due to the high relevance of time as a decisive success (or stress) factor in information overload-related situations for managers (e.g., Bawden and Robinson 2009; Pennington and Tuttle 2007; Schick et al. 1990; Tushman and Nadler 1978), the results of information overload studies including a strong reference to time are interesting for all disciplines of business administration.

5 Values as of April 30, 2018 (https://www.journals.elsevier.com/computers-in-human-behavior).
} 


\section{Descriptive results of the bibliometric analysis}

Prior literature reviews on information overload stated that information (over-)load research reached a peak in the 1980s and 1990s, but interest in this topic declined in the early 2000s (Eppler and Mengis 2004; Ding and Beaulieu 2011; Lewis 1996; Edmunds and Morris 2000; Feather 1988). Considering the development of information overload research after Eppler and Mengis (2004)'s review, two trends could be revealed: First, the number of peer-reviewed journal publications on information overload per year across all areas of research significantly increase per year, $\beta=12.374, t(11)=25.194, p<0.001$ (see Fig. 2). Second, publications in business research-relevant journals are somewhat left behind, and their increase per year is slightly unstable when compared to total publications, $\beta=0.742$, $t(11)=2.417, p<0.05$. Since 2005, the development has been characterized by strong outlays with lows particularly in 2006, 2009 and 2015 and with peaks in 2007 and 2012 (see Fig. 3). Although a chart depicting the number of publications on information overload cannot show a cause and effect relationship, the significant OLS-regressions regarding the increase in publications could be a first hint. Moreover, I find a significant correlation $(\rho=0.740, p<0.01)$ between the number of publications in business research-relevant journals and the total number of peerreviewed journal publications on information overload per year across all areas of research.

\subsection{Publications in business research-relevant journals}

Regarding the publications in business research-relevant journals, a comparison between disciplines of business research shows that the top five disciplines driving research forward on information overload in business administration are information systems and computer science, marketing, general management, logistics, and accounting (see Table 1). Particularly in information systems and computer science,

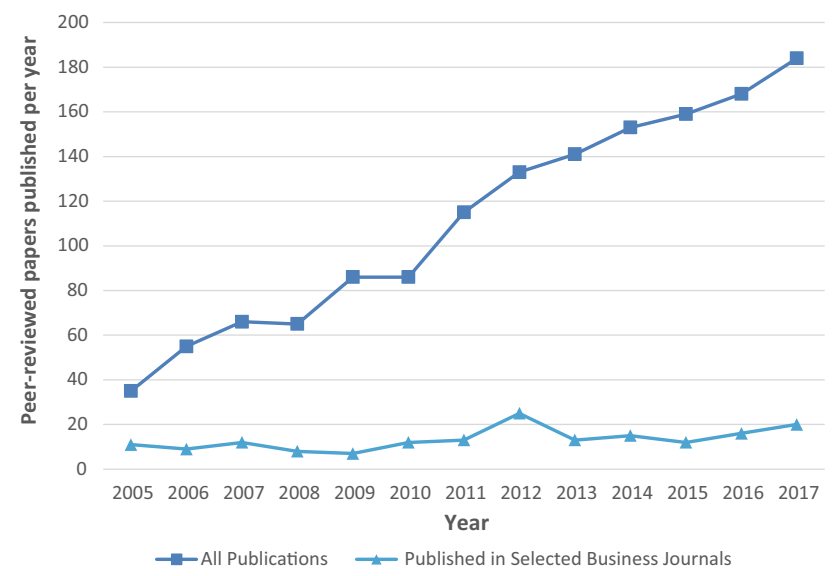

Fig. 2 Historical development of the number of information overload publications 


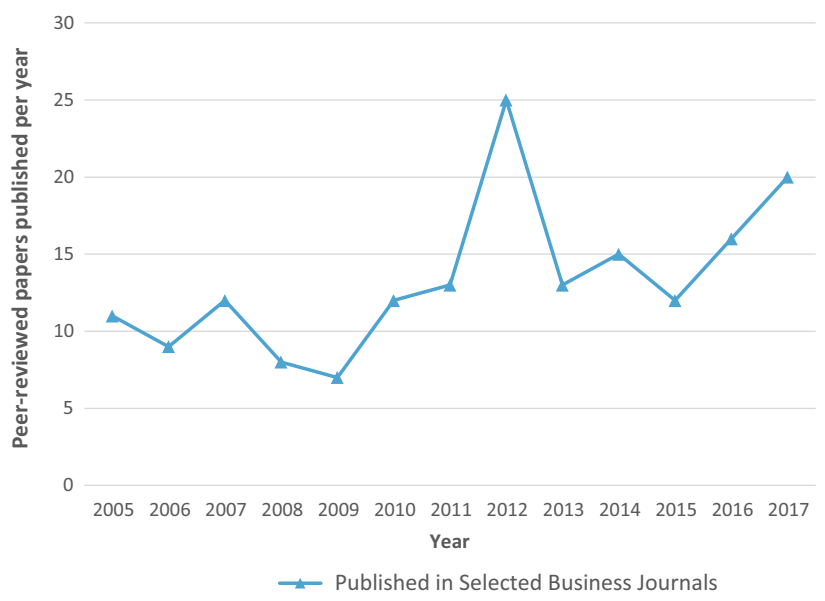

Fig. 3 Historical development of the number of information overload publications in business researchrelevant journals

two journals publish $74.68 \%$ of all research articles in this field: decision support systems and computers in human behavior. The strong IS-related research can be found in the other top disciplines, e.g., in accounting, and the top publishing journal is the International Journal of Accounting Information Systems. The role of computer- or IS-based decision-making is often the starting point or a mediator/moderator.

Table 1 Publications in business research-relevant journals

\begin{tabular}{lccc}
\hline Discipline & No. of journals & Publications & Share (\%) \\
\hline Information systems and computer science & 14 & 83 & 42.13 \\
Marketing & 10 & 28 & 14.21 \\
General management & 14 & 27 & 13.71 \\
Logistics & 2 & 19 & 9.64 \\
Accounting & 5 & 10 & 5.08 \\
Human resources & 4 & 8 & 4.06 \\
Finance & 3 & 7 & 3.55 \\
Operations research & 3 & 6 & 3.05 \\
Innovation and entrepreneurship & 3 & 3 & 1.52 \\
Organization & 3 & 3 & 1.52 \\
Environmental management & 1 & 1 & 0.51 \\
Health economics & 1 & 1 & 0.51 \\
Public administration & 1 & 1 & 0.51 \\
Total (multiple assignment possible) & 66 & 197 & 100 \\
\hline
\end{tabular}


Table 2 Publications in business research-relevant journals for different rating categories

\begin{tabular}{lcr}
\hline VHB rating & Number of publications $(\%)$ & \\
\hline A & 8 & 4.23 \\
A & 34 & 17.99 \\
B & 96 & 50.79 \\
C & 31 & 16.40 \\
Listed but not ranked & 2 & 1.06 \\
Not listed & 18 & 9.52 \\
Total & 189 & 100.00 \\
\hline
\end{tabular}

Table 2 shows the distribution of publications regarding the VHB-JOURQUAL3 categories. The majority of publications belong to "B"-rated journals. A Kolmogorov-Smirnov test with the Lilliefors significance correction indicates a normal distribution $(p>0.05)$. Only eight papers are published in "A+"-rated journals. Here, a temporary peak occurs in 2006/07 when four of the eight papers are published. The results do not reveal any correlation between time and journal rating.

\subsection{Authorship}

Regarding authorship, Schaltegger et al. (2013) draw on the "Ortega hypothesis" (Cole and Cole 1972), which implies that scientific progress is based on the work of a small percentage and number of researchers and authors in each field. While prior work questions this hypothesis (e.g., Száva-Kováts 2004), I analyzed whether any authors were dominant in the field of information overload. In the business researchrelevant sample of 189 papers from 462 different authors, no authors published more than 3 papers. In the total sample of 1537 papers from 818 different authors, one author has ten publications (Fred Paas), and 7 authors have five publications. Thus, I find no indication for the "Ortega hypothesis" in business-relevant information overload research.

\subsection{Methodological approaches and underlying theories}

Different methodological approaches exist for analyzing the literature on information overload. Between 2005 and 2017, 21.16\% of the published papers are nonempirical (e.g., conceptual), whereas $78.84 \%$ draw on empirical methods. This review shows the heterogeneity of methods typically used to detect information overload.

In information overload research, the two dominating research methods are lab experiments and surveys (Table 3). Drawing on Hair et al. (2007), documenting effects in field research (e.g., by surveys) is important to test the external validity of experimental research (e.g., lab experiments). While lab research is very well suited to test theories, it is limited in its external validity. Thus, findings may not occur in practice, and laboratory research must be taken to the field to test its relevance. Next to lab experiments, researchers use online experiments to get more information on 
Table 3 Publications in business research-relevant journals for methods

\begin{tabular}{lcc}
\hline Research method & No. of publications & Share $(\%)$ \\
\hline Lab experiment & 57 & 30.16 \\
Survey & 54 & 28.57 \\
Conceptual & 22 & 11.64 \\
Archival data & 16 & 8.47 \\
Simulation & 9 & 4.76 \\
Case study & 8 & 4.23 \\
Online experiment & 6 & 3.17 \\
Review articles & 5 & 2.65 \\
Qualitative interviews & 4 & 2.12 \\
Combinatorial optimization & 4 & 2.12 \\
Meta-analysis & 3 & 1.59 \\
Field experiment & 1 & 0.53 \\
Total & 189 & 100.00 \\
\hline
\end{tabular}

user behavior (e.g., in social networks). Field experiments or mixed methods, however, can be considered "rare orchid" methods, playing a negligible niche role in information overload research, although these methods might have the strength of a field approach that shows effects occurring in the workplace (Hair et al. 2007; Wang et al. 2014). While prior research has found many single leverage points that affect information search, information processing, and decision-making behavior, comprehensive and overarching studies are missing. Due to the limitations of lab experiments and surveys (Birnberg et al. 2008; Luft and Shields 2003; Sprinkle and Williamson 2008), new empirical methods such as action research or a combination of field experiments, surveys and archival data within larger companies might provide deeper insights into information overload.

\section{New conceptual model for information overload-related research}

The described lack of a common definition of information overload might root in the distinct heterogeneity of theoretical backgrounds used (see Table 4). The mostused theory is the human information processing approach by Schroder et al. (1967), on which the working definition of information overload has been based. Similar to the second most-used theory_-information processing approach by Miller (1956) the human information processing approach by Schroder et al. (1967) makes general assumptions about how decision-makers process information but do not limit the range of possible applications in research. Surprisingly, $35.45 \%$ of the papers do not use a theory but argue logically. 
Table 4 Publications in business research-relevant journals regarding theoretical backgrounds

\begin{tabular}{ll}
\hline Theoretical background & $\begin{array}{l}\text { No. of } \\
\text { publications }\end{array}$ \\
\hline
\end{tabular}

Human information processing approach by Schroder et al. (1967) 27 Share

Information processing approach by Miller (1956)

19

Cognitive load theory

Information overload approach by Malhotra et al. (1982)

Information theory

Principal agent theory synthesized with assumptions of bounded rationality

Wilson's (1999) model of information behavior

Attention deficit disorder/attention deficit trait

Bounded rationality

News communication approach by Rogers and Agarwala-Rogers (1975)

Additive information approach by Butters (1977)

1.06

1.06

1.06

Affect and social behavior approach by Moore and Isen (1990)

0.53

Affect infusion model by Forgas (1995)

0.53

Classical choice theory

0.53

Cognitive load theory synthesized with social capital theory

0.53

Communication theory

0.53

Constructive processing perspective by Payne et al. (1992)

0.53

Cultural management approach by Hofstede and Hofstede (2005)

0.53

Distraction conflict theory

0.53

Dual-process theory

0.53

Filter model of attention by Broadbent (1958)

0.53

0.53

Hierarchy of effects model synthesized with information overload approach by Malhotra et al. (1982)

Human information processing approach by Schroder et al. (1967) synthesized with prospect theory

Information diffusion theory based on epidemiology susceptible-infectedrecovered-susceptible (SIRS) models by Bailey (1975)

Information overload approach by Malhotra et al. (1982) synthesized with paralysis by analysis approach by Lewis (1996)

Information overload concept by O'Reilly (1980)

Information processing approach by Miller (1956) synthesized with filter model of attention by Broadbent (1958)

Information processing approach by Miller (1956) synthesized with news communication approach by Rogers and Agarwala-Rogers (1975)

Information processing approach by Miller (1956) synthesized with SMCR model by Berlo (1960)

Information processing approach by Miller (1956) synthesized with mood congruency approach by Forgas and George (2001)

Information use approach by Stigler (1961)

Information weighting approach by Wedell and Senter (1997)

0.53

Input-processing-output (IPO) model

Job burn-out approach by Maslach and Jackson (1981)

Knowledge-based view 
Table 4 continued

\begin{tabular}{lcc}
\hline Theoretical background & $\begin{array}{l}\text { No. of } \\
\text { publications }\end{array}$ & $\begin{array}{c}\text { Share } \\
(\%)\end{array}$ \\
\hline $\begin{array}{l}\text { Knowledge-based view synthesized with organizational learning approach by } \\
\text { Huber (1991) }\end{array}$ & 1 & 0.53 \\
Need for cognition approach & 1 & 0.53 \\
Organization of decentralized information processing approach by Radner & 1 & 0.53 \\
$\quad$ (1993) & & 0.53 \\
Organizational learning approach by Shrivastava (1983) synthesized with & 1 & 0.53 \\
$\quad$ Lindblom's (1959) concept of incrementalism & & 0.53 \\
Passive bounded rationality model by DeShazo and Fermo (2002) & 1 & 0.53 \\
Personal construct theory by Kelly (1955) & 1 & 1 \\
Prospect theory & 1 & 0.53 \\
Relational complexity model by Halford et al. (1998) & 1 & 0.53 \\
Sensemaking approach by Weick (1995) & 1 & 0.53 \\
Social cognition theory & 1 & 0.53 \\
Strength of weak ties approach by Granovetter (1983), theory of affordances & 1 & 0.53 \\
Theory of semantic internalization & 1 & 0.53 \\
Transactional theory of stress & 1 & 35.4 \\
No explicit theory addressed/argumentation with empirical evidence only & 67 & 100 \\
Total & & 189 \\
\hline
\end{tabular}

The occurrence of such a range of theories and approaches reveals a need to conceptualize research areas and survey and synthesize prior research using a framework. Following the recommendations of Webster and Watson (2002), I structured prior research in a thorough framework.

Eppler and Mengis (2004) used a conceptual framework, structuring research on information overload as a cycle (causes $\rightarrow$ symptoms $\rightarrow$ countermeasures $\rightarrow$ causes). By contrast, I arrange these elements as a functional chain to structure the research (see Fig. 4); this structure allows me to follow the psychological understanding of the prior management literature. Mental processes and states are interpreted as mediators between a stimuli and a behavior (Birnberg et al. 2008). By focusing on the individual instead of organizations or societies, management psychology explains "subjective phenomena" (Birnberg et al. 2008, p. 115).

Furthermore, a thorough framework is missing that spans from the starting situation to the information search and selection via information processing to decision-making and to the ex post consequences of the decision. Prior approaches can capture the steps between, such as Wilson's (1999) model of information behavior, which focuses on information seeking and information satisfaction in a documentation/library setting, or the Factor-Based Model of Jackson and Farzaneh 


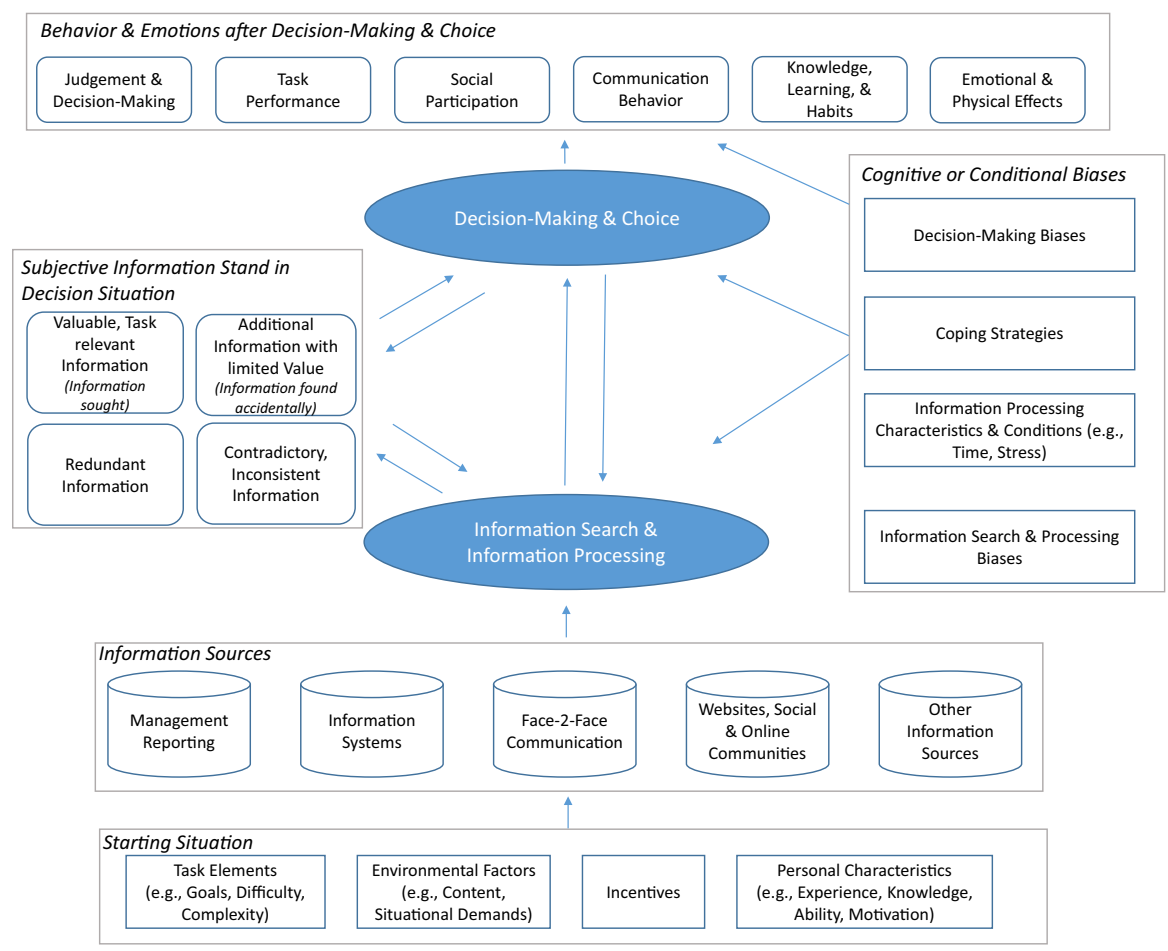

Fig. 4 Framework

(2012), which approaches information overload as a scale of information underload and overload.

Thus, a framework is developed that categorizes the important elements relevant to information overload research as derived from the analyzed articles and shows the relationships between these elements. Considering the big picture, the empirical literature on information load is characterized by concrete, highly detailed empirical research with very specific studies using a wide range of theoretical backgrounds. These studies primarily focus on the following broad topic areas:

1. Which ex ante starting situation leads to changes in information processing behavior and/or decision-making?

2. What role does the source of information (e.g., information system, communication, database, social media, websites, online communities) play in information search, information processing, and decision-making? How does the type of information source affect an individual's behavior in information search, processing and decision-making?

3. Which biases occur during information search and processing (e.g., evaluation, editing)? How do information processing characteristics and conditions (e.g., limited time, stress) affect information search and processing? 
4. How does the processing of information itself influence the subjective informational stance of the decision-maker in the decision situation?

5. What effects do these identified influences and biases have on information overload and how does information overload affect the situation after the decision has been made (e.g., judgement, task performance, behavior, emotions)?

These broad topic areas can be clustered into five categories relevant to decisionmaking in information overload situations: starting situation, information sources, information search and information processing, subjective information stance in decision-making situations, decision-making and choice, and behavior and emotions ex post.

The arrows drawn in Fig. 4 represent the major steps in the functional chain. For reasons of clarity and comprehensibility, I do not map the overarching arrows (e.g., personal characteristics $\rightarrow$ information search and processing biases, personal characteristics $\rightarrow$ motives or personal characteristics $\rightarrow$ judgement and decisionmaking). Furthermore, relationships might run in the opposite direction (e.g., judgement and decision-making $\rightarrow$ information sources or communication behavior $\rightarrow$ source preferences).

Information overload is seen as a decisive issue across all disciplines within business administration and economics, but aside from a range of case applications (see Tables 5, 6, 7, 8, 9), new fundamental theory-building research is missing. The reason for this lack is that human cognitive processes are most often seen as a black box-except in recent studies in neuroeconomics (Denham 2015; Oizumi et al. 2014). While empirical studies draw on theoretical models of the most-cited theoretical literature (e.g., the human information processing approach by Schroder et al. (1967), the information processing approach by Miller (1956), or information theory (Shannon and Weaver 1959)), comprehensive empirical testing is lacking for recent theoretical findings in neuroeconomics (Denham 2015; Oizumi et al. 2014).

First, the category starting situation includes the ex ante-relevant factors influencing the information search, information processing and decision-making process. It comprises the characteristics of the task or the decision to be made (e.g., level of difficulty, complexity, goals), the environmental factors that affect the situation in which the decision-making process begins (e.g., context, situational demand), the personal characteristics of the decision-maker (e.g., experience, knowledge, ability, motivation) and the incentives present (e.g., decision performance links to variable payment). This category contains the elements that might lead to biased behaviors on the next steps and that might be the starting point of information overload. The known effects of starting situation aspects on information processing, decision-making and the occurrence of information overload are shown in Table 5.

The next category is information sources, which plays a decisive role in overload situations. The selection of information sources and the decision-makers' source preferences are fundamental to determining what he or she will consider in his or her information search and information processing. The subjective perception of the characteristics of the source (e.g., trust, reputation) and the characteristics of 
Table 5 Known effects of starting situation aspects on information processing, decision-making and the occurrence of information overload

\begin{tabular}{|c|c|c|c|}
\hline $\begin{array}{l}\text { Aspect of } \\
\text { starting situation }\end{array}$ & Factor influencing information overload & Discipline & References \\
\hline \multirow[t]{14}{*}{ Task element } & \multirow{4}{*}{$\begin{array}{l}\text { Task complexity and task } \\
\text { interdependency }\end{array}$} & $\mathrm{ACC}$ & Ding and Beaulieu (2011), Simnet (1996) \\
\hline & & IS & $\begin{array}{l}\text { Gupta et al. (2013), Speier et al. } \\
\quad(1999,2003), \text { Wang et al. (2014) }\end{array}$ \\
\hline & & MAR & Hunter and Goebel (2013) \\
\hline & & MS & Kock (2000), Tushman and Nadler (1978) \\
\hline & Task novelty, task too innovative & MS & $\begin{array}{l}\text { Tushman and Nadler (1978), Herbig and } \\
\text { Kramer (1994) }\end{array}$ \\
\hline & Task interdisciplinarity & IM/LS & Bawden (2001), Foster (2004) \\
\hline & Varying task priorities & IS & Sharma et al. (2014) \\
\hline & Goal specificity & IS & Tam and Ho (2006) \\
\hline & $\begin{array}{l}\text { Information collection and availability } \\
\text { is a company goal }\end{array}$ & IS & Farhoomand and Drury (2002) \\
\hline & \multirow[t]{2}{*}{ Decision-maker's attention } & ECS & Anderson and de Palma (2012) \\
\hline & & IS & Hargittai et al. (2012), Tam and Ho (2006) \\
\hline & $\begin{array}{l}\text { Overall diversity of the provided } \\
\text { information in task }\end{array}$ & $\mathrm{ACC}$ & Iselin (1988) \\
\hline & $\begin{array}{l}\text { Number of alternatives/attributes/ } \\
\text { options }\end{array}$ & MAR & $\begin{array}{l}\text { Greifeneder et al. (2010), Scheibehenne } \\
\text { et al. (2010) }\end{array}$ \\
\hline & Multitasking & IS & Tarafdar et al. (2010) \\
\hline \multirow[t]{19}{*}{ Environment } & \multirow[t]{2}{*}{ Heterogenous groups } & IS & $\begin{array}{l}\text { Grise and Gallupe (1999/2000), Wilson } \\
\quad \text { (1996) }\end{array}$ \\
\hline & & $\mathrm{SCM}$ & Hult et al. (2004) \\
\hline & \multirow[t]{2}{*}{ Virtual collaboration } & IS & $\begin{array}{l}\text { Bawden (2001), Grise and Gallupe (1999/ } \\
\text { 2000), Jones et al. (2004), Paul and } \\
\text { Nazareth (2010), Speier et al. (1999) }\end{array}$ \\
\hline & & MAR & Schultze and Vandenbosch (1998) \\
\hline & Use of information control instruments & MAR & Ariely (2000), Wu and Lin (2006) \\
\hline & $\begin{array}{l}\text { Personalized information } \\
\text { services/portals/interfaces }\end{array}$ & $\begin{array}{l}\text { IS } \\
\text { MS }\end{array}$ & $\begin{array}{l}\text { Tam and Ho (2006), Wang et al. (2014) } \\
\text { Sherer et al. (2003) }\end{array}$ \\
\hline & Technology adaption too high & ECS & Cukrowski and Baniak (1999) \\
\hline & Choice-rich environment & ECS & Hensher (2006) \\
\hline & Herd behavior of others & IS & Hu and Lai (2013) \\
\hline & Frequency/occurrence of interruptions & IS & $\begin{array}{l}\text { Gupta et al. (2013), McCoy et al. (2007), } \\
\text { Speier et al. (1999), Speier et al. (2003) }\end{array}$ \\
\hline & Technostress at workplace & IS & D'Arcy et al. (2014) \\
\hline & Cultural background & MS & $\begin{array}{l}\text { Borkovich and Morris (2012), Klausegger } \\
\quad \text { et al. (2007) }\end{array}$ \\
\hline & Project overload & IS, MS & Caniëls and Bakens (2012) \\
\hline & \multirow[t]{2}{*}{ Number of network contacts } & IS & Sasaki et al. (2015) \\
\hline & & MS & Sherer et al. (2003) \\
\hline & $\begin{array}{l}\text { Overly high organizational use of } \\
\text { information and communications } \\
\text { technologies (ICT)/IT-driven } \\
\text { environment }\end{array}$ & IS & $\begin{array}{l}\text { Allen and Shoard (2005), Bucher et al. } \\
\text { (2013), Moore (2000), Soucek and } \\
\text { Moser (2010), Tarafdar et al. (2010) }\end{array}$ \\
\hline & Role overload & MAR & Hunter and Goebel (2013) \\
\hline & Perceived fearful corporate culture & PSY & Hallowell (2005) \\
\hline & High technology dependency & IS & Karr-Wisniewski and Lu (2010) \\
\hline
\end{tabular}


Table 5 continued

\begin{tabular}{|c|c|c|c|}
\hline $\begin{array}{l}\text { Aspect of } \\
\text { starting situation }\end{array}$ & Factor influencing information overload & Discipline & References \\
\hline \multirow[t]{2}{*}{ Incentives } & Performance-based monetary incentives & $\mathrm{ACC}$ & $\begin{array}{l}\text { Awasthi and Pratt (1990), Tuttle and } \\
\text { Burton (1999) }\end{array}$ \\
\hline & Mood congruency bias & ACC & Ding and Beaulieu (2011) \\
\hline \multirow[t]{26}{*}{$\begin{array}{l}\text { Personal } \\
\quad \text { characteristics }\end{array}$} & $\begin{array}{l}\text { Limited information processing } \\
\text { ability/capacity }\end{array}$ & $\mathrm{ACC}$ & $\begin{array}{l}\text { Chewning and Harrell (1990), Greiling and } \\
\text { Spraul (2010), Pennington and Tuttle } \\
\text { (2007), Shields (1980, 1983), Simnet } \\
\text { (1996) }\end{array}$ \\
\hline & & FI & $\begin{array}{l}\text { Bouwman et al. (1993), Lev and } \\
\text { Thiagarajan (1993), Rogers and Grant } \\
\text { (1997) }\end{array}$ \\
\hline & & IS & $\begin{array}{l}\text { Davis and Ganeshan (2009), Hiltz and } \\
\text { Turoff (1985), Shrivastav and Hiltz } \\
\text { (2013) }\end{array}$ \\
\hline & & MAR & $\begin{array}{l}\text { Herbig and Kramer (1994), Lee and Lee } \\
\text { (2004), Lurie (2004) }\end{array}$ \\
\hline & & MS & O'Reilly (1980) \\
\hline & Prior knowledge and experience & FI & Agnew and Szykman (2005) \\
\hline & & IS & Saunders et al. (2017) \\
\hline & & MAR & $\begin{array}{l}\text { Bettman and Park (1980), Chen et al. } \\
\text { (2009), Owen (1992), Wu and Lin } \\
\text { (2006) }\end{array}$ \\
\hline & $\begin{array}{l}\text { General personal characteristics/ } \\
\text { demographics (e.g., age, gender) }\end{array}$ & IS & $\begin{array}{l}\text { Holton and Chyi (2012), Sasaki et al. } \\
\text { (2015) }\end{array}$ \\
\hline & & PSY, IM & Benselin and Ragsdell 2016 \\
\hline & Polychronic attitude & MAR & Hunter and Goebel (2013) \\
\hline & Work stress & MS & Klausegger et al. (2007) \\
\hline & Epistemic motivation & PSY & Amit and Sagiv (2013) \\
\hline & Awareness & IS & Saparova et al. (2013) \\
\hline & Information avoidance tendency & $\mathrm{HE}$ & Case et al. (2005) \\
\hline & Health status & $\mathrm{HE}$ & Chan and Huang (2013) \\
\hline & & PSY & Hallowell (2005) \\
\hline & User's allegiance & IS & Hsu and Liao (2014) \\
\hline & Fairness attitude & IS & Roetzel and Lohmann (2014) \\
\hline & Risk attitude & ACC & Pennington and Tuttle (2007) \\
\hline & & IS & Davis and Ganeshan (2009) \\
\hline & Star employee status & HR & Oldroyd and Morris (2012) \\
\hline & Mood & $\mathrm{ACC}$ & Ding and Beaulieu (2011) \\
\hline & & MS & Braun-LaTour et al. (2007) \\
\hline & Psychological ill-being & HE, IS & Swar et al. (2017) \\
\hline & Personal skills & ORG, IS & Whelan and Teigland (2013) \\
\hline
\end{tabular}

ACC accounting, ECS economics, $F I$ finance, $H E$ health economics/management, $H R$ human resources, IM/LS information management/library science, IN innovation management, INTM international management, IS information systems, $M A R$ consumer research/marketing, $M F$ manufacturing, $M S$ management science/general management, $O R G$ organizational science, $P S Y$ psychology 
Table 6 Known effects of information source aspects on information processing, decision-making and the occurrence of information overload

\begin{tabular}{|c|c|c|c|}
\hline $\begin{array}{l}\text { Aspect of } \\
\text { information } \\
\text { sources }\end{array}$ & $\begin{array}{l}\text { Factor influencing } \\
\text { information overload }\end{array}$ & Discipline & References \\
\hline \multirow[t]{5}{*}{ Databases } & $\begin{array}{c}\text { Relationship internal/ } \\
\text { external databases }\end{array}$ & MS & Klausegger et al. (2007) \\
\hline & $\begin{array}{l}\text { External knowledge } \\
\text { sources }\end{array}$ & IS & Dong and Netten (2017) \\
\hline & $\begin{array}{l}\text { Market knowledge } \\
\text { acquisition }\end{array}$ & IN & Zhou and Li (2012) \\
\hline & $\begin{array}{l}\text { Amount and complexity of } \\
\text { user reviews }\end{array}$ & IS & Fink et al. (2018) \\
\hline & Website complexity & IS & $\begin{array}{l}\text { Chen (2018), Lin (2006), Rodríguez-Molina et al. (2015), } \\
\text { Wang et al. (2014) }\end{array}$ \\
\hline \multirow[t]{6}{*}{$\begin{array}{l}\text { Social } \\
\text { networks }\end{array}$} & \multirow[t]{2}{*}{$\begin{array}{l}\text { Participation in social } \\
\text { networks }\end{array}$} & IS & $\begin{array}{l}\text { Koroleva and Bolufe-Röhler (2012), Li and Sun (2014), } \\
\text { Sasaki et al. (2015) }\end{array}$ \\
\hline & & HR & Oldroyd and Morris (2012) \\
\hline & $\begin{array}{l}\text { Strength of ties to other } \\
\text { network users }\end{array}$ & IS & Koroleva and Kane (2016) \\
\hline & Herd behavior & IS & Hu and Lai (2013) \\
\hline & $\begin{array}{l}\text { Number of friends/ } \\
\text { network ties }\end{array}$ & IS & Koroleva and Kane (2016), Sasaki et al. (2015) \\
\hline & Social media news speed & IS & Lee et al. (2017) \\
\hline \multirow[t]{17}{*}{$\begin{array}{l}\text { Information } \\
\text { source } \\
\text { design }\end{array}$} & $\begin{array}{l}\text { Suboptimal management } \\
\text { information system } \\
\text { design }\end{array}$ & IS & Ackoff (1967) \\
\hline & $\begin{array}{l}\text { Suboptimal information } \\
\text { source presentation } \\
\text { mode }\end{array}$ & IS & Wheeler and Arunachalam (2009) \\
\hline & \multirow{2}{*}{$\begin{array}{l}\text { Suboptimal platform } \\
\text { design }\end{array}$} & MAR & Chen et al. (2009), Holton and Chyi (2012), Li (2016) \\
\hline & & $\mathrm{HE}$ & Cartwright et al. (2002) \\
\hline & System feature overload & IS & Lee et al. (2016) \\
\hline & System feature use & IS & Sasaki et al. (2015) \\
\hline & $\begin{array}{l}\text { Content recommendation/ } \\
\text { personalization }\end{array}$ & IS & $\begin{array}{l}\text { Aljukhadar et al. (2012), Chen et al. (2016), Liang et al. } \\
\text { (2007), Xiao and Benbasat (2007), Zhang et al. (2018) }\end{array}$ \\
\hline & \multirow{2}{*}{$\begin{array}{l}\text { Additional, unwanted } \\
\text { information provided }\end{array}$} & MAR & Wu and Lin (2006) \\
\hline & & IS & McCoy et al. (2007) \\
\hline & $\begin{array}{l}\text { Provided information } \\
\quad \text { filtering tools }\end{array}$ & MAR & Chen et al. (2009) \\
\hline & \multirow[t]{2}{*}{ Provision of search agents } & IS & Yen et al. (2006) \\
\hline & & MAR & Alba et al. (1997) \\
\hline & Media (over-)richness & IS & Wheeler and Arunachalam (2009) \\
\hline & $\begin{array}{l}\text { Cyber-based information } \\
\text { search only }\end{array}$ & PSY & Misra and Stokols (2012) \\
\hline & \multirow{3}{*}{$\begin{array}{l}\text { Use of push/pull } \\
\text { information systems }\end{array}$} & $\mathrm{HE}$ & Wilson (2001) \\
\hline & & IM/LS & Edmunds and Morris (2000), Herther (1998) \\
\hline & & MS & Klausegger et al. (2007) \\
\hline
\end{tabular}


Table 6 continued

\begin{tabular}{llll}
\hline $\begin{array}{l}\text { Aspect of } \\
\text { information } \\
\text { sources }\end{array}$ & $\begin{array}{l}\text { Factor influencing } \\
\text { information overload }\end{array}$ & Discipline & References \\
\hline $\begin{array}{l}\text { Source } \\
\text { preferences }\end{array}$ & Trust & IS & $\begin{array}{c}\text { Kim and Benbasat (2009), Koroleva and Kane (2016), } \\
\text { Xiao and Benbasat (2007) }\end{array}$ \\
\hline
\end{tabular}

engaging with the source (e.g., convenience of information collection, ease of operation, information provided per query) contribute essentially to the effectiveness of information search and information processing — or to information overload. This category also includes the availability, clarity and comprehensibility of information gathered by external sources. Note that this category addresses external information sources from the decision-maker's viewpoint. Internal information sources (e.g., memory) are not included in this category but are part of the next category [note that even internal sources of information might lead to biases, e.g., the availability bias studied by Kahneman (2011)]. The known effects of Information Sources aspects on information processing, decision-making and the occurrence of information overload are shown in Table 6.

The third category is information search and information processing (including aspects of information processing characteristics and conditions), which represents the actual process through which the decision-maker searches for and processes information. This category includes the search, evaluation, editing, and weighting of information. A range of business administration and economic theories focus on these steps, e.g., prospect theory (Tversky and Kahneman 1974). Information search and information processing is related triangularly to subjective information stance in decision-making situations and decision-making and choice. This triangle reflects the insight of cognitive management psychology that decision-making and choice might precede search and evaluation (e.g., in confirmation bias situations (Tversky and Kahneman 1974)). The present framework allows consideration of these situations (decision-making and choice before information search and information processing) but allows alternative directions (information search and information processing before decision-making and choice) as well. The known effects of information search and information processing aspects on information processing, decision-making and the occurrence of information overload are shown in Table 7.

Subjective information stand in decision situation is the fourth category. This category captures what information decision-makers have actually processed and what information value they have gained as a result. This category must be established because from the decision-making process view, when the decisionmaker completes information search and information processing, the subjective information stance is the essential starting point for decision-making. This category differentiates between four different types of information: 
Table 7 Known effects of information search, information processing and its characteristics and conditions on further information search and processing, decision-making and the occurrence of information overload

\begin{tabular}{|c|c|c|c|}
\hline Aspect & $\begin{array}{l}\text { Factor influencing } \\
\text { information } \\
\text { overload }\end{array}$ & Discipline & References \\
\hline \multirow{22}{*}{$\begin{array}{l}\text { Information } \\
\text { characteristics }\end{array}$} & \multirow{5}{*}{$\begin{array}{l}\text { Information } \\
\text { complexity }\end{array}$} & $\mathrm{ACC}, \mathrm{FI}$ & Plumlee (2003) \\
\hline & & ECS & Hensher (2006) \\
\hline & & IS & Paul and Nazareth (2010) \\
\hline & & MAR & $\begin{array}{l}\text { Lee and Lee (2004), Li (2016), Lurie (2004), } \\
\text { Reutskaja and Hogarth (2009) }\end{array}$ \\
\hline & & MS & $\begin{array}{l}\text { Amit and Sagiv (2013), Driver and Streufert } \\
\text { (1969), Schneider (1987) }\end{array}$ \\
\hline & \multirow[t]{4}{*}{$\begin{array}{l}\text { Amount of } \\
\text { information }\end{array}$} & $\mathrm{ACC}$ & $\begin{array}{l}\text { Casey (1980), Chewning and Harrell (1990), } \\
\text { Roetzel (2014), Roetzel et al. (2015), Shields } \\
\text { (1980, 1983), Simnet (1996) }\end{array}$ \\
\hline & & MAR & $\begin{array}{l}\text { Herbig and Kramer (1994), Jacoby et al. (1974), } \\
\text { Jacoby (1977, 1984), Malhotra et al. (1982), } \\
\text { Malhotra (1984), Schultze and Vandenbosch } \\
\text { (1998), Wang et al. (2007) }\end{array}$ \\
\hline & & $\mathrm{HE}$ & Swar et al. (2017) \\
\hline & & IS & $\begin{array}{l}\text { Borkovich and Morris (2012), Gao et al. (2018), } \\
\text { Hiltz and Turoff (1985), Davis and Ganeshan } \\
\text { (2009), Shrivastav and Hiltz (2013) }\end{array}$ \\
\hline & $\begin{array}{l}\text { Novelty of } \\
\text { information }\end{array}$ & MS & Schneider (1987) \\
\hline & Search depth & IS & Lin (2006) \\
\hline & \multirow{4}{*}{$\begin{array}{l}\text { Ambiguity/diversity } \\
\text { of information }\end{array}$} & MS & Schneider (1987), Schroder et al. (1967) \\
\hline & & $\mathrm{ACC}$ & Iselin (1988) \\
\hline & & $\mathrm{HE}$ & Slawson et al. (1994) \\
\hline & & MAR & Li (2016), Lurie (2004) \\
\hline & \multirow[t]{2}{*}{$\begin{array}{l}\text { Information } \\
\text { accessibility }\end{array}$} & IS & $\begin{array}{l}\text { Hsu and Liao (2014), Roetzel and Lohmann } \\
\text { (2014) }\end{array}$ \\
\hline & & MAR & Schultze and Vandenbosch (1998) \\
\hline & $\begin{array}{l}\text { Information } \\
\text { equivocality }\end{array}$ & IS & Lee and Lee (2004) \\
\hline & $\begin{array}{l}\text { Information } \\
\text { structure }\end{array}$ & MAR & Lurie (2004) \\
\hline & $\begin{array}{l}\text { Threat of } \\
\text { information } \\
\text { unavailability }\end{array}$ & IS & $\begin{array}{l}\text { Davis and Ganeshan (2009), Tushman and } \\
\text { Nadler (1978) }\end{array}$ \\
\hline & $\begin{array}{l}\text { Share of redundant } \\
\text { information }\end{array}$ & IS & Lee et al. (2016) \\
\hline & $\begin{array}{l}\text { Use of incremental } \\
\text { analysis methods }\end{array}$ & MS & Bettis-Outland (2012) \\
\hline
\end{tabular}


Table 7 continued

\begin{tabular}{llll}
\hline Aspect & $\begin{array}{l}\text { Factor influencing } \\
\text { information } \\
\text { overload }\end{array}$ & Discipline & References \\
\hline Conditions & $\begin{array}{l}\text { Time pressure/ } \\
\text { restrictions }\end{array}$ & ACC & $\begin{array}{c}\text { Pennington and Tuttle (2007), Schick et al. } \\
(1990)\end{array}$ \\
& IS & $\begin{array}{l}\text { Hiltz and Turoff (1985), Paul and Nazareth } \\
(2010)\end{array}$ \\
& MAR & $\begin{array}{l}\text { Scheibehenne et al. (2010) } \\
\text { Kock (2000) } \\
\text { Mahn et al. (1992), Misuraca and Teuscher } \\
\text { (2013) }\end{array}$ \\
& PSY & Gao et al. (2012), Messner and Wänke (2011) \\
Unconscious & IS & \\
\hline
\end{tabular}

- Valuable task-relevant information: The value of information is determined by its utility for decision-making. Information that increases the decision-maker's insight and understanding of a decision situation obtains a higher value, whereas information that is useless to the decision-maker in the decision situation obtains a lower value. The valuable task-relevant information is the share of information for which the decision-maker actually searched.

- Additional information with limited value: The share of information that the decision-maker found accidentally but can use to some extent for decisionmaking.

- Redundant information: The share of information whose value depends on the decision maker's intention and on the sequence of information search and information processing, and decision-making and choice. If information search and information processing precedes decision-making and choice, then redundant information has a limited-to-negative value for decision makers because it does not increase his or her understanding of the decision situation but ties up cognitive resources (i.e., information processing capacity). Otherwise (i.e., decision-making and choice before information search and information processing), if the decision maker wants to justify an already made decision (e.g., in confirmation bias or self-justification situations), the redundant information might have a positive marginal utility because it underpins the already-made decision. The latter is a subjective value from the decisionmaker's viewpoint.

- Contradictory, inconsistent information: The share of information that contradicts the decision-maker's evaluation so far. On the one hand, the decisionmaker might tend to ignore or discard such information [e.g., to avoid cognitive dissonance (Festinger 1954)]. On the other hand, such information might urge the decision-maker to search for further information to obtain a clearer evaluation. 
Table 8 Known effects of subjective information in decision situation on decision-making and the occurrence of information overload

\begin{tabular}{|c|c|c|c|}
\hline Aspect/bias & Effect & Discipline & References \\
\hline $\begin{array}{l}\text { Attractive } \\
\text { stimulus } \\
\text { overload }\end{array}$ & $\begin{array}{l}\text { Increasing number of information and choices in } \\
\text { decision situations lead to intrapersonal conflicts }\end{array}$ & PSY & Lipowski (1970) \\
\hline \multirow[t]{12}{*}{$\begin{array}{l}\text { Information } \\
\text { search }\end{array}$} & \multirow[t]{2}{*}{ Decrease in the proportion of information searched } & $\mathrm{ACC}$ & $\begin{array}{l}\text { Anderson (1988), } \\
\text { Swain and Haka } \\
(2000)\end{array}$ \\
\hline & & MS & Payne (1976) \\
\hline & \multirow[t]{3}{*}{ Increase of variability in information search } & $\mathrm{ACC}$ & $\begin{array}{l}\text { Anderson (1988), } \\
\text { Swain and Haka } \\
(2000)\end{array}$ \\
\hline & & IS & Cook (1993) \\
\hline & & MS & Payne (1976) \\
\hline & Less systematic search strategy & $\mathrm{ACC}$ & $\begin{array}{l}\text { Swain and Haka } \\
\text { (2000) }\end{array}$ \\
\hline & \multirow[t]{2}{*}{ Increase of noncompensatory search patterns } & $\mathrm{ACC}$ & $\begin{array}{l}\text { Pennington and } \\
\text { Tuttle (2007) }\end{array}$ \\
\hline & & IS & Cook (1993) \\
\hline & Discard/ignore search results & PSY & Case et al. 2005 \\
\hline & \multirow[t]{2}{*}{ Use of search agents } & MAR & Alba et al. (1997) \\
\hline & & IS & $\begin{array}{l}\text { Lau et al. (2001), } \\
\text { Yen et al. (2006) }\end{array}$ \\
\hline & Personal interest while searching & MAR & Alba et al. (1997) \\
\hline \multirow[t]{8}{*}{$\begin{array}{l}\text { Information } \\
\text { processing }\end{array}$} & \multirow[t]{4}{*}{$\begin{array}{l}\text { Highly selective information selection and } \\
\text { processing }\end{array}$} & MAR & $\begin{array}{l}\text { Herbig and Kramer } \\
\text { (1994) }\end{array}$ \\
\hline & & IS & $\begin{array}{l}\text { Hiltz and Turoff } \\
\text { (1985), Osburg } \\
\text { et al. (2016) }\end{array}$ \\
\hline & & IM/LS & $\begin{array}{l}\text { Bawden (2001), } \\
\text { Edmunds and } \\
\text { Morris (2000) }\end{array}$ \\
\hline & & IN & Sparrow (1999) \\
\hline & Incongruent information response & MAR & $\begin{array}{l}\text { Braun-LaTour et al } \\
\quad(2007)\end{array}$ \\
\hline & \multirow[t]{2}{*}{ Attention of decision-maker } & MAR & $\begin{array}{l}\text { Sicilia and Ruiz } \\
\text { (2010) }\end{array}$ \\
\hline & & ECS & $\begin{array}{l}\text { Anderson and de } \\
\text { Palma (2012) }\end{array}$ \\
\hline & Affordance of decision-maker & IS & $\begin{array}{l}\text { Koroleva and Kane } \\
\text { (2016) }\end{array}$ \\
\hline
\end{tabular}


Table 9 Known effects of information overload on decision-maker's behavior and emotions after decision-making and choice ex post

\begin{tabular}{|c|c|c|c|}
\hline $\begin{array}{l}\text { Aspect of behavior and } \\
\text { emotions after decision- } \\
\text { making and choice }\end{array}$ & $\begin{array}{l}\text { Result of information } \\
\text { overload/reaction due to } \\
\text { information overload }\end{array}$ & Discipline & References \\
\hline \multirow[t]{15}{*}{ Task performance } & \multirow[t]{6}{*}{$\begin{array}{l}\text { Decreasing decision- } \\
\text { making performance }\end{array}$} & $\mathrm{ACC}$ & $\begin{array}{l}\text { Abdel-Khalik (1973), Chewning and } \\
\text { Harrell (1990), Schick et al. } \\
\text { (1990), Shields (1980) }\end{array}$ \\
\hline & & FI & $\begin{array}{l}\text { Agnew and Szykman (2005), } \\
\text { Spindler (2011), Ward and } \\
\text { Ramachandran (2010) }\end{array}$ \\
\hline & & IS & $\begin{array}{l}\text { Gupta et al. (2013), Okike and } \\
\text { Fernandes (2012), Speier et al. } \\
\text { (1999), Scott (2005), Speier et al. } \\
\text { (2003), Ward and Ramachandran } \\
\text { (2010) }\end{array}$ \\
\hline & & MAR & $\begin{array}{l}\text { Chen et al. (2009), Hunter and } \\
\text { Goebel (2013), Jacoby et al. } \\
\text { (1974), Jacoby (1984), Keller and } \\
\text { Staelin (1987), Korhonen et al. } \\
\text { (2018), Malhotra (1984), Malhotra } \\
\text { et al. (1982), Meyer (1998) }\end{array}$ \\
\hline & & IM/LS & $\begin{array}{l}\text { Bawden (2001), Bawden and } \\
\text { Robinson (2009), Hwang and Lin } \\
\text { (1999), Edmunds and Morris } \\
\text { (2000) }\end{array}$ \\
\hline & & PSY & $\begin{array}{l}\text { Hallowell (2005), Misra and Stokols } \\
\quad(2012)\end{array}$ \\
\hline & $\begin{array}{l}\text { Confusion regarding the } \\
\text { decision }\end{array}$ & MAR & $\begin{array}{l}\text { Jacoby et al. (1974), Malhotra et al. } \\
\text { (1982) }\end{array}$ \\
\hline & $\begin{array}{l}\text { Decision delayed or } \\
\text { canceled }\end{array}$ & MAR & Sicilia and Ruiz (2010) \\
\hline & \multirow[t]{3}{*}{$\begin{array}{l}\text { Decreasing decision } \\
\text { satisfaction }\end{array}$} & MAR & $\begin{array}{l}\text { Jacoby (1984), Messner and Wänke } \\
\text { (2011), Reutskaja and Hogarth } \\
\text { (2009) }\end{array}$ \\
\hline & & IS & Davis and Ganeshan (2009) \\
\hline & & IM/LS & Bawden and Robinson (2009) \\
\hline & $\begin{array}{l}\text { Increase in decision } \\
\text { satisfaction }\end{array}$ & ACC & O’Reilly (1980) \\
\hline & \multirow{2}{*}{$\begin{array}{l}\text { Decrease/lack/reduction } \\
\text { of attention level }\end{array}$} & MAR & Sicilia and Ruiz (2010) \\
\hline & & IS & Li and Sun (2014) \\
\hline & $\begin{array}{l}\text { Radical innovation } \\
\text { generation }\end{array}$ & IN & Zhou and Li (2012) \\
\hline
\end{tabular}


Table 9 continued

\begin{tabular}{|c|c|c|c|}
\hline $\begin{array}{l}\text { Aspect of behavior and } \\
\text { emotions after decision- } \\
\text { making and choice }\end{array}$ & $\begin{array}{l}\text { Result of information } \\
\text { overload/reaction due to } \\
\text { information overload }\end{array}$ & Discipline & References \\
\hline \multirow[t]{6}{*}{ Judgement } & \multirow[t]{4}{*}{$\begin{array}{l}\text { Decreasing judgement } \\
\text { accuracy/efficiency/ } \\
\text { performance }\end{array}$} & $\mathrm{ACC}$ & $\begin{array}{l}\text { Pennington and Kelton (2016), } \\
\text { Pennington and Tuttle (2007), } \\
\text { Shields (1983), Simnet (1996) }\end{array}$ \\
\hline & & FI & $\begin{array}{l}\text { Agnew and Szykman (2005), Hilary } \\
\text { and Menzly (2006), Hilton (2010), } \\
\text { Spindler (2011) }\end{array}$ \\
\hline & & IS & Lankton et al. (2012) \\
\hline & & MAR & $\begin{array}{l}\text { Ketron et al. (2016), Sicilia and Ruiz } \\
\text { (2010), Summers (1974) }\end{array}$ \\
\hline & $\begin{array}{l}\text { Decreasing prediction } \\
\text { performance }\end{array}$ & $\mathrm{ACC}$ & Snowball $(1979,1980)$ \\
\hline & $\begin{array}{l}\text { Greater tolerance of } \\
\text { error }\end{array}$ & MS & Sparrow (1999) \\
\hline \multirow{7}{*}{$\begin{array}{l}\text { Communication } \\
\text { behavior }\end{array}$} & \multirow{2}{*}{$\begin{array}{l}\text { Increasing } \\
\text { communication } \\
\text { intensity }\end{array}$} & HR & Oldroyd and Morris (2012) \\
\hline & & IS & $\begin{array}{l}\text { Chen and Lee (2013), Li and Sun } \\
\text { (2014) }\end{array}$ \\
\hline & $\begin{array}{l}\text { Reduction of } \\
\text { communication } \\
\text { intensity }\end{array}$ & MS & Schneider (1987) \\
\hline & $\begin{array}{l}\text { Simplification of } \\
\text { communication }\end{array}$ & IS & Jones et al. (2004) \\
\hline & $\begin{array}{l}\text { Word-of-mouth } \\
\text { activities }\end{array}$ & MAR & $\begin{array}{l}\text { Gottschalk and Mafael (2017), Hutter } \\
\text { et al. (2013) }\end{array}$ \\
\hline & $\begin{array}{l}\text { Reduction of technology } \\
\text { acceptance }\end{array}$ & IS & Swar et al. (2017) \\
\hline & $\begin{array}{l}\text { Social network service } \\
\text { fatigue }\end{array}$ & IS & Lee et al. (2016) \\
\hline \multirow[t]{2}{*}{ Social participation } & $\begin{array}{l}\text { Reduction of active } \\
\text { participation in social } \\
\text { communities }\end{array}$ & IS & $\begin{array}{l}\text { Jones et al. (2004), Zha et al. (2018), } \\
\text { Zhang et al. (2016) }\end{array}$ \\
\hline & $\begin{array}{l}\text { Unfriend/unfollow } \\
\text { behavior }\end{array}$ & IS & Sasaki et al. (2015) \\
\hline
\end{tabular}


Table 9 continued

\begin{tabular}{|c|c|c|c|}
\hline $\begin{array}{l}\text { Aspect of behavior and } \\
\text { emotions after decision- } \\
\text { making and choice }\end{array}$ & $\begin{array}{l}\text { Result of information } \\
\text { overload/reaction due to } \\
\text { information overload }\end{array}$ & Discipline & References \\
\hline \multirow[t]{20}{*}{$\begin{array}{l}\text { Knowledge, learning, } \\
\text { and habits }\end{array}$} & $\begin{array}{l}\text { Learning to handle } \\
\text { overload over time }\end{array}$ & MAR & Ariely 2000 \\
\hline & $\begin{array}{l}\text { Project management } \\
\text { information system } \\
\text { quality decreases }\end{array}$ & IS, MS & Caniëls and Bakens (2012) \\
\hline & E-mail-free workdays & IM/LS & Bawden and Robinson (2009) \\
\hline & \multirow{2}{*}{$\begin{array}{l}\text { Change of coping } \\
\text { strategy }\end{array}$} & IS & Scott (2005), Zeldes et al. (2007) \\
\hline & & MS & $\begin{array}{l}\text { Ledzińska and Postek (2017), } \\
\text { Luedicke et al. (2017), Savolainen } \\
\text { (2007) }\end{array}$ \\
\hline & $\begin{array}{l}\text { Slower adaption of IT/ } \\
\text { ICT }\end{array}$ & IS & Maes (1994) \\
\hline & \multirow{3}{*}{$\begin{array}{l}\text { Growing into } \\
\text { specialized filtering } \\
\text { habits/roles }\end{array}$} & MAR & Wu and Lin (2006) \\
\hline & & IS & Schuff et al. (2006) \\
\hline & & ORG & Whelan and Teigland (2013) \\
\hline & \multirow[t]{2}{*}{$\begin{array}{l}\text { Information distribution } \\
\text { behavior }\end{array}$} & MF, IS & $\begin{array}{l}\text { Okike and Fernandes (2012), Scott } \\
\text { (2005) }\end{array}$ \\
\hline & & SCM & Hult et al. (2004) \\
\hline & $\begin{array}{l}\text { Disruption of } \\
\text { established cognitive } \\
\text { processes }\end{array}$ & HE, PSY & $\begin{array}{l}\text { Cartwright et al. (2002), Sweller et al. } \\
\quad \text { (1983), Sweller (1988) }\end{array}$ \\
\hline & $\begin{array}{l}\text { Change of user } \\
\text { preference }\end{array}$ & IS & McCoy et al. (2007) \\
\hline & $\begin{array}{l}\text { Acceleration of } \\
\text { decision-making } \\
\text { behavior }\end{array}$ & $\mathrm{ACC}$ & Pennington and Tuttle (2007) \\
\hline & Increase of overtime & MS & Klausegger et al. (2007) \\
\hline & $\begin{array}{l}\text { Change in } \\
\text { organizational } \\
\text { learning }\end{array}$ & MS & Wei and Ram (2016) \\
\hline & $\begin{array}{l}\text { Knowledge acquisition } \\
\text { and retrieval }\end{array}$ & IS & Lankton et al. (2012) \\
\hline & \multirow{3}{*}{$\begin{array}{l}\text { Use of push/pull } \\
\text { information systems }\end{array}$} & MS & Klausegger et al. (2007) \\
\hline & & IM/LS & $\begin{array}{l}\text { Edmunds and Morris (2000), Herther } \\
\text { (1998) }\end{array}$ \\
\hline & & $\mathrm{HE}$ & Wilson (2001) \\
\hline
\end{tabular}


Table 9 continued

\begin{tabular}{|c|c|c|c|}
\hline $\begin{array}{l}\text { Aspect of behavior and } \\
\text { emotions after decision- } \\
\text { making and choice }\end{array}$ & $\begin{array}{l}\text { Result of information } \\
\text { overload/reaction due to } \\
\text { information overload }\end{array}$ & Discipline & References \\
\hline \multirow{17}{*}{$\begin{array}{l}\text { Emotions and personal } \\
\text { state }\end{array}$} & \multirow[t]{2}{*}{ Lower job satisfaction } & MAR & Hunter and Goebel (2013) \\
\hline & & MS & O’Reilly (1980) \\
\hline & User satisfaction & IS & Liang et al. (2007) \\
\hline & $\begin{array}{l}\text { Lower satisfaction with } \\
\text { the organizational } \\
\text { communication }\end{array}$ & MS & O'Reilly (1980) \\
\hline & \multirow[t]{3}{*}{ Overconfidence } & MAR & Jacoby (1984), Meyer (1998) \\
\hline & & MR & O’Reilly (1980) \\
\hline & & PSY & Hallowell (2005) \\
\hline & $\begin{array}{l}\text { Increased distractibility/ } \\
\text { impatience }\end{array}$ & IM/LS & Bawden and Robinson (2009) \\
\hline & Demotivation & MS & Baldacchino et al. (2002) \\
\hline & $\begin{array}{l}\text { Tendency for job } \\
\text { turnover }\end{array}$ & IS & Moore (2000) \\
\hline & \multirow[t]{5}{*}{ Stress/technostress } & $\mathrm{ACC}$ & Schick et al. (1990) \\
\hline & & MAR & Malhotra (1984) \\
\hline & & IS & $\begin{array}{l}\text { D'Arcy et al. (2014), Lee et al. } \\
\text { (2016), Plotnick et al. (2009) }\end{array}$ \\
\hline & & MS & $\begin{array}{l}\text { Klausegger et al. (2007), Ledzińska } \\
\text { and Postek (2017) }\end{array}$ \\
\hline & & PSY & Misra and Stokols (2012) \\
\hline & Poorer health status & PSY & $\begin{array}{l}\text { Hallowell (2005), Misra and Stokols } \\
\quad(2012)\end{array}$ \\
\hline & $\begin{array}{l}\text { Increase of negative } \\
\text { emotions (anger, } \\
\text { depression) }\end{array}$ & IS & Swar et al. (2017) \\
\hline
\end{tabular}

The known effects of subjective information stance in decision situation aspects on information processing, decision-making and the occurrence of information overload are shown in Table 8.

The fifth category is decision-making and Choice. This step is the third part of the triangular relationship with information search and information processing and subjective information stance in decision-making situations. This category consists of the decision step of the decision-making process: the selection of one of the existing alternatives. While the process of information search and information processing is affected by a variety of possible biases, it is prone to such biases as well [e.g., bounded rationality (Simon 1955), overconfidence (Tversky and Kahneman 1974), and emotionally driven decision-making on impulse (Forgas 1995; Moore and Isen 1990)].

Last, the category behavior and emotions after decision-making and choice describe the results of the decision-making process, including the effects on the 
individual decision-maker (e.g., emotions, choice satisfaction, communication behavior, knowledge, habits), the relevant task or purpose of the decision-making process (e.g., task performance, judgement, decision-making performance), and the consequences for the organization (e.g., social participation, corporate performance as an outcome of individual performance). The known effects of behavior and emotions after decision-making and choice aspects on information processing, decision-making and the occurrence of information overload are shown in Table 9.

\section{Recent trends and add-ons in information overload literature 2005-2017}

Comparing the business administration literature with the literature overview by Eppler and Mengis (2004), this situation clearly remains unchanged. The level of citations is very low for the business administration literature and neuroeconomics in the area of information overload (Eppler and Mengis 2004).

Most studies analyzed in this literature review consider up to three of the five possible categories of my framework. Due to the limitations of empirical research (Birnberg et al. 2008; Luft and Shields 2003), and experimental research in particular, no study depicts the entire framework shown in Fig. 4. Hence, the empirical research on information overload is quite fragmented. This situation is compounded by the fact that each discipline within business administration and economics applies its own focus and tool kit to analyze information overload. While management accounting research identifies information overload as a negative mediator affecting the impact of a stimuli (e.g., management control system) on behavior (Birnberg et al. 2008), IS research focuses on IS design and user preferences (Borkovich and Morris 2012; Johansson et al. 2014). More recently, marketing research has treated information overload as a proxy for choice overload, which in turn reduces the likelihood of triggering a purchase decision (Scheibehenne et al. 2010).

Furthermore, a range of conceptual papers identify information overload issues in a variety of disciplines in business administration, in particular in accounting (e.g., Greiling and Spraul 2010; Oluwadare and Samy 2015), information systems research (e.g., Cartwright et al. 2002; D’Arcy et al. 2014; Li and Sun 2014), international management (e.g., Borkovich and Morris 2012), marketing (e.g., Anderson and de Palma 2012), organizational science (e.g., Bettis-Outland 2012), and economics (e.g., Cukrowski and Baniak 1999). In the following, I describe the tendencies of the recent research identified in the framework's five categories (see Fig. 4).

Furthermore, and following the methodology of Ramnath et al. (2008), I differentiate by discipline to indicate the different analytical lenses and subjects of these disciplines.

To ensure compatibility to prior literature reviews, in particular to the interdisciplinary review of Eppler and Mengis (2004), I provide tables with known effects on and of information overload. Here, I combine the recently analyzed 
effects and the effects reported in prior literature reviews to facilitate a big picture of each category.

Furthermore, I draw on my framework to identify "hotspots" of information overload research as well as areas "off the beaten track" which would significantly add to the big picture of information overload. Table 10 shows that the majority of information overload studies focus on topic along the major steps in the functional chain [146 of $189(77.25 \%)]$. The remaining papers conduct research within the five categories. The paths "information sources $\rightarrow$ behavior and emotions after decision-making and choice", "cognitive or conditional biases $\rightarrow$ behavior and emotions after decision-making and choice", and "starting situation $\rightarrow$ behavior and emotions after decision-making and choice" are intensively investigated $(59.58 \%)$.

From a bird's eye perspective, I see three larger trends in research on information overload. On the one hand, one may argue that subsuming the heterogeneous field of information overload literature is an exaggeration towards simplification. On the other hand, a practical alternative might be to use the range of paths in Table 5 to define the relevant trends. In the latter, one would identify 18 different trends instead of four. In the light of this trade-off, I decided to take four trends- to avoid that the reader runs into the danger of suffering from information overload.

\subsection{Trend I: "Information overload as a design issue-caused by the (mis- )use of computers and information systems"}

This major trend draws on a long stream of research rooting in the seminal paper named "Management Misinformation Systems" by Ackoff (1967). While the core issue of providing a too high amount of information or too complex information when using management information systems, databases, etc., may confuse its users, it may also affect their ability to prioritize or complicate the retrieval of information (Farhoomand and Drury 2002; Hiltz and Turoff 1985). Retrospectively, the digitalization and virtualization of the decision-making environment dominate the literature, which is primarily driven by IS research. Reducing information overload is one of the major challenges of IS research in the information age (Dean and Webb 2011). While an information system may facilitate greater information flow (potentially leading to overload), it also has the potential to help decisionmakers organize, store, and process information. Nevertheless, MISs are seen as one of the major causes of information overload in information and communication technology (ICT)-related tasks (Levitin 2014; Shapiro and Varian 2013). Here, information overload has been shown to lead to decreases in decision performance in virtual communication (e.g., Jones et al. 2004; D'Arcy et al. 2014), to less systematic and less thorough search strategies (e.g., Paul and Nazareth 2010; Hiltz and Turoff 1985).

The issue causing information overload is the same as described by Ackoff (1967): while the system is getting more efficient, the user adapts in a vastly slower way. The user's personal characteristics seem to play a very important role regarding individual thought patterns, which affect information search, information 
Table 10 Recent research within the framework

\begin{tabular}{|c|c|c|c|}
\hline Beginning at... & $\begin{array}{l}\text { No of } \\
\text { publications }\end{array}$ & Ending at... & $\begin{array}{l}\text { No of } \\
\text { publications }\end{array}$ \\
\hline \multirow[t]{4}{*}{ Starting situation } & \multirow[t]{4}{*}{41} & Information sources & 3 \\
\hline & & Information search and processing & 6 \\
\hline & & Decision-making and choice & 6 \\
\hline & & $\begin{array}{l}\text { Behavior and emotions after decision- } \\
\text { making and choice }\end{array}$ & 26 \\
\hline \multirow[t]{3}{*}{ Information sources } & \multirow[t]{3}{*}{43} & Information search and processing & 7 \\
\hline & & Decision-making and choice & 4 \\
\hline & & $\begin{array}{l}\text { Behavior and emotions after decision- } \\
\text { making and choice }\end{array}$ & 32 \\
\hline \multirow[t]{3}{*}{$\begin{array}{l}\text { Information search and } \\
\text { processing }\end{array}$} & \multirow[t]{3}{*}{12} & $\begin{array}{l}\text { Subjective information stand in } \\
\text { decision situation }\end{array}$ & 1 \\
\hline & & Decision-making and choice & 8 \\
\hline & & $\begin{array}{l}\text { Behavior and emotions after decision- } \\
\text { making and choice }\end{array}$ & 3 \\
\hline \multirow{3}{*}{$\begin{array}{l}\text { Subjective information stand in } \\
\text { decision situation }\end{array}$} & \multirow[t]{3}{*}{12} & Information search and processing & 1 \\
\hline & & Decision-making and choice & 5 \\
\hline & & $\begin{array}{l}\text { Behavior and emotions after decision- } \\
\text { making and choice }\end{array}$ & 6 \\
\hline \multirow[t]{5}{*}{ Cognitive or conditional biases } & \multirow[t]{5}{*}{38} & Information search and processing & 1 \\
\hline & & Cognitive or conditional biases & 1 \\
\hline & & $\begin{array}{l}\text { Subjective information stand in } \\
\text { decision situation }\end{array}$ & 2 \\
\hline & & Decision-making and choice & 5 \\
\hline & & $\begin{array}{l}\text { Behavior and emotions after decision- } \\
\text { making and choice }\end{array}$ & 29 \\
\hline
\end{tabular}

processing, and decision-making behavior (e.g., Allen and Shoard 2005; Benselin and Ragsdell 2016; Hunter and Goebel 2013).

The prior research regarding system or user adaption is characterized by a strong orientation toward "hard" technical characteristics such as algorithm efficiency, availability, compatibility, system feature design, and visualization (see Table 6). In the last decade, there have been few approaches to the "soft" characteristics (e.g., subjective user experience and trust) that shift the focus from a more technical viewpoint to a psychological viewpoint (e.g., Koroleva and Bolufe-Röhler 2012; $\mathrm{Wu}$ and Lin 2006).

One major aspect of information processing is not in the focus of researchers yet: how information can be processed and evaluated by "intelligent" information systems. While decision support systems or decision aid are widely investigated, the wide field of machine learning, deep learning and artificial intelligence, which is one of the most important drivers of digitalization, is not linked with information overload literature yet. 


\subsection{Trend II: "Information overload as a virus—spreading through (social) media and news networks"}

People do consume more information via the internet than ever before (Levitin 2014). Not surprisingly, the dominant discipline in research on information sources and its effects on information search, information processing, and decision-making behavior is IS research. The consideration of information processing and decisionmaking on the cloud applications and over social media environments is readily observable (e.g., Jones et al. 2004; Sasaki et al. 2015; Tarafdar et al. 2010).

Essential topics of research studies in the last decade draw on the rapid development of the web and the vast amount of information provided on different channels and portals such as online news streams (e.g., Holton and Chyi 2012), online shopping (e.g., Li 2016; Wu and Lin 2006) and social network sites (e.g., Koroleva and BolufeRöhler 2012; Koroleva and Kane 2016 Lee et al. 2016). Another relevant topic, particularly in marketing research, is the effect and efficiency of (pop-up) ads and other channels for unwanted advertising (e.g., McCoy et al. 2007).

The common finding of these research studies is that information overload does not scare users to use these channels or platforms. Users seem to ignore possible side effects of information overload up to a very high level before retreating from these channels or platforms. From a bird's eye perspective, this situation might be compared with the spread of a disease. Thus, people often act irrationally by infecting others (i.e., sending more messages, likes, news to other members of their network) instead of sparing themselves (i.e., making a rest/recovery from their overloaded status).

Moreover, while prior research in other disciplines finds that trust affects the information weighting behavior of decision-makers (e.g., in risk management (Earle 2010; Slovic 1993) or innovation management (Bstieler 2006; Staples and Webster 2008)), the role of trust in information selection in potential information overload situations is widely unclear-except for the study of Koroleva and Kane (2016), which focuses on Facebook users and trust issues but is not applicable to most business situations.

The intensive use of social media and the steady exposition to information overload might cause emotional, mental and physical effects. In the last decade, there are studies which focus on mental (e.g., Braun-LaTour et al. 2007; Hallowell 2005) and physical health parameters (e.g., Chan and Huang 2013), showing information overload's negative effects on emotions (e.g., Swar et al. 2017) and on perceived health (e.g., Hallowell 2005; Misra and Stokols 2012). Information overload does not only affect working behavior, but also leads to less time devoted to contemplative activities (Misra and Stokols 2012).

\subsection{Trend III: "Information overload as an "search obstacle"-new ways to circuit and adaptions in information search and processing"}

Based on the trinity of the three articles of Miller (1956), Newell and Simon (1972) and Schroder et al. (1967), the inverted U-shaped relationship is replicated and confirmed in the last decade (e.g., Davis and Ganeshan 2009; Roetzel 2014; Sicilia and Ruiz 2010). There is a shift in research from the focus on the amount of 
information towards the focus on the complexity (Lee and Lee 2004; Li 2016; Lurie 2004; Reutskaja and Hogarth 2009) and interdependence of information (e.g., Amit and Sagiv 2013; Lankton et al. 2012; Wang et al. 2014).

Moreover, recent research shifts the spotlight on typical work situations affected by the information age such as production (e.g., Okike and Fernandes 2012), innovation (e.g., Zhou and Li 2012) or consumer-relevant decisions in households (e.g., Hensher 2006), risk judgements (Pennington and Tuttle 2007) or virtual work (Paul and Nazareth 2010). Furthermore, negative effects of the information age and user-centered aspects in virtual environments are investigated by research (e.g., user attention (e.g., Anderson and de Palma 2012; Sicilia and Ruiz 2010) or affordance (e.g., Koroleva and Kane 2016)). These studies show that the fundamental issue of biased information search is replicable in new work environments.

The main driver of information search and processing issues is a usual suspect known since the 1960s: limited time (Schroder et al. 1967). Time pressure and time restrictions often lead to information overload (Misuraca and Teuscher 2013; Scheibehenne et al. 2010). Thus, human information search and processing biases are still used to getting their way in digitalized environments.

However, there is a lack of research investigating sources of stress other than time regarding information search and processing. Other stress factors such as selfinduced stress (e.g., aspiration level) are still under-researched. These stress factors do not need to be linked to the task; often, employees face stress factors that are not considered or measurable by the organization (Levitin 2014).

In the information age, there is a need for research to clarify how an oversupply of information might affect known cognitive biases. While prior research on information search suggests that information search and information processing are affected by cognitive biases such as self-justification and that decision-makers react to unpleasant situations or information stands by acquiring even more information (e.g., Schultze et al. 2012), studies on information overload are missing.

Moreover, psychological research shows that decision-makers react differently when information is retrospective or prospective (e.g., Conlon and Parks 1987; Schultze et al. 2012). This might open interesting avenues for further research because decision-makers often receive retrospective and/or prospective information (e.g., corporate planning, budgeting). Further research should analyze whether decision-makers react differently when facing an overly high level of retrospective versus prospective information.

In strategies on coping these information search and processing biases, three major directions are visible in recent research: the technology-centered view including the use of technical countermeasures (e.g., filter agents, search protocols, visualization), which has slightly increased (e.g., Koroleva and Bolufe-Röhler 2012); the human-centered view to consider the decision-maker's behavior or emotional or physical effects (e.g., stress reduction), which is essentially driven by IS research (e.g., D'Arcy et al. 2014; Lee et al. 2016; Plotnick et al. 2009); and the information process-centered view, which draws on countermeasures to address the complexity and mass of information (e.g., Lee and Lee 2004; Paul and Nazareth 2010; Sumecki et al. 2011). The three approaches tackle different categories of the framework. In Table 11, the different categories are assigned to the three views. 
Table 11 Coping strategies

\begin{tabular}{|c|c|c|c|c|}
\hline View & Leverage point & Strategy & Discipline & References \\
\hline \multirow{12}{*}{$\begin{array}{l}\text { Human- } \\
\text { centered } \\
\text { view }\end{array}$} & \multirow{6}{*}{$\begin{array}{c}\text { Decision-maker's } \\
\text { emotional and } \\
\text { physical effects }\end{array}$} & \multirow{5}{*}{$\begin{array}{l}\text { Reduction of } \\
\text { stress }\end{array}$} & $\mathrm{ACC}$ & Schick et al. (1990) \\
\hline & & & IS & $\begin{array}{l}\text { D'Arcy et al. (2014, Lee et al. } \\
\quad(2016) \text {, Plotnick et al. (2009) }\end{array}$ \\
\hline & & & MAR & Malhotra (1984) \\
\hline & & & MS & Klausegger et al. (2007) \\
\hline & & & PSY & Misra and Stokols (2012) \\
\hline & & $\begin{array}{l}\text { Improvement of } \\
\text { mood }\end{array}$ & $\mathrm{ACC}$ & Ding and Beaulieu (2011) \\
\hline & \multirow{6}{*}{$\begin{array}{l}\text { Starting situation } \\
\text { (personal } \\
\text { characteristics) }\end{array}$} & \multirow{3}{*}{$\begin{array}{l}\text { ICT-related } \\
\text { method } \\
\text { training (e.g., } \\
\text { prioritization) }\end{array}$} & $\mathrm{ACC}$ & Schick et al. (1990) \\
\hline & & & IM/LS & Bawden (2001) \\
\hline & & & IS & Sumecki et al. (2011) \\
\hline & & $\begin{array}{l}\text { Time- } \\
\text { management } \\
\text { training }\end{array}$ & IM/LS & Bawden (2001) \\
\hline & & $\begin{array}{l}\text { Withdrawal } \\
\text { strategy }\end{array}$ & MS & Savolainen (2007) \\
\hline & & $\begin{array}{l}\text { Discarding } \\
\text { information } \\
\text { strategy }\end{array}$ & IS & Holton and Chyi (2012) \\
\hline \multirow{9}{*}{$\begin{array}{l}\text { Information } \\
\text { processing- } \\
\text { centered } \\
\text { view }\end{array}$} & \multirow{4}{*}{$\begin{array}{l}\text { Starting situation } \\
\text { (information } \\
\text { characteristics) }\end{array}$} & \multirow[t]{3}{*}{$\begin{array}{l}\text { Complexity } \\
\text { reduction }\end{array}$} & $\mathrm{ACC}$ & $\begin{array}{l}\text { Greiling and Spraul (2010), Iselin } \\
\quad \text { (1988) }\end{array}$ \\
\hline & & & IS & $\begin{array}{l}\text { Ackoff (1967), Grise and Gallupe } \\
\text { (1999/2000), Hiltz and Turoff } \\
\text { (1985), Lee and Lee (2004), } \\
\text { Paul and Nazareth (2010), } \\
\text { Sumecki et al. (2011) }\end{array}$ \\
\hline & & & MAR & Lurie (2004) \\
\hline & & $\begin{array}{l}\text { Reduction of the } \\
\text { amount of } \\
\text { information }\end{array}$ & IS & Davis and Ganeshan (2009) \\
\hline & \multirow{3}{*}{$\begin{array}{l}\text { Starting situation } \\
\quad \text { (task } \\
\text { characteristics) }\end{array}$} & \multirow{3}{*}{$\begin{array}{l}\text { Improvement of } \\
\text { goal } \\
\text { specificity/link } \\
\text { to incentives }\end{array}$} & $\mathrm{ACC}$ & Tuttle and Burton (1999) \\
\hline & & & IS & Tam and Ho (2006) \\
\hline & & & MS & Baldacchino et al. (2002) \\
\hline & \multirow{2}{*}{$\begin{array}{l}\text { Information search } \\
\text { and information } \\
\text { processing } \\
\text { (conditions) }\end{array}$} & \multirow[t]{2}{*}{$\begin{array}{l}\text { Relaxation of } \\
\text { time pressure }\end{array}$} & $\mathrm{ACC}$ & $\begin{array}{l}\text { Pennington and Tuttle (2007), } \\
\text { Schick et al. (1990) }\end{array}$ \\
\hline & & & MAR & Scheibehenne et al. (2010) \\
\hline \multirow{6}{*}{$\begin{array}{l}\text { Technology- } \\
\text { centered } \\
\text { view }\end{array}$} & \multirow[t]{2}{*}{$\begin{array}{l}\text { Decision-maker's } \\
\text { behavior }\end{array}$} & \multirow{2}{*}{$\begin{array}{l}\text { Focus on filtering } \\
\text { information/ } \\
\text { use of filter } \\
\text { algorithms }\end{array}$} & IS & $\begin{array}{l}\text { Koroleva and Bolufe-Röhler } \\
\text { (2012) }\end{array}$ \\
\hline & & & MS & Savolainen (2007) \\
\hline & \multirow[t]{4}{*}{ Information source } & \multirow{2}{*}{$\begin{array}{l}\text { Enhancement of } \\
\text { visualization }\end{array}$} & IM/LS & Chan (2001) \\
\hline & & & MAR & Meyer (1998) \\
\hline & & \multirow[t]{2}{*}{$\begin{array}{l}\text { Improvement of } \\
\text { (search) agents }\end{array}$} & IS & $\begin{array}{l}\text { Berghel (1997), Edmunds and } \\
\text { Morris (2000), Maes (1994) }\end{array}$ \\
\hline & & & MAR & Alba et al. (1997) \\
\hline
\end{tabular}




\section{Conclusions}

Discovering the effects of information search, selection, processing, and evaluation in the decision-making process and the occurring biases and limitations is key for out understanding of the decision-making process itself. This study incorporates a wide range of effects from the starting situation ex ante to the decision consequences ex post.

In conclusion, this review has some limitations to address. First, I include business-related research only and exclude other research fields (e.g., pedagogy). There might be insights into these areas which are relevant for business administration research as well. Further research might address this limitation. Second, I searched for the keywords "information overload", "information load", "cognitive load", and "cognitive overload". There might be relevant studies on information overload or related topics which do not use these keywords in their titles or abstracts. While the snowball sampling (Biernacki and Waldorf 1981) might be a valid strategy to reduce such errors, there might be further articles which are not cited in this review.

In this paper, I have provided some perspective on possible avenues of research regarding information overload following the three major trends. The avenues for future research that seem the most promising to me include the following. First, the interdisciplinary research regarding the link between digitalization, virtual organizations, and business psychology is a decisive uprising research direction, following the call for research from Eppler and Mengis (2004). Second, there is little research done to enhance our understanding of the interlinks between all five categories. Prior research merely focused on one to three of the categories. I look forward to research clarifying the interdependencies between the influence factors of the categories. More research is needed to understand the interaction between decisionmaker's emotions, his or her decision-making-related information processing, and the virtualness of the environment. I expect this research to have implications for emerging concepts and theories regarding virtual collaboration in organizations. Third, I encourage researchers to continue exploring the factors that make some decision-makers better information processors than others in different tasks and environments.

Open Access This article is distributed under the terms of the Creative Commons Attribution 4.0 International License (http://creativecommons.org/licenses/by/4.0/), which permits unrestricted use, distribution, and reproduction in any medium, provided you give appropriate credit to the original author(s) and the source, provide a link to the Creative Commons license, and indicate if changes were made.

\section{References}

Abdel-Khalik, A.R. 1973. The effect of aggregating accounting reports on the quality of the lending decision: An empirical investigation. Journal of Accounting Research 11 (Suppl): 104-138.

Ackoff, Russell L. 1967. Management misinformation systems. Management Science 14 (4): 147-156. https://doi.org/10.1287/mnsc.14.4.B147. 
Agnew, Julie R., and Lisa R. Szykman. 2005. Asset allocation and information overload: The influence of information display, asset choice, and investor experience. Journal of Behavioral Finance 6 (2): 57-70. https://doi.org/10.1207/s15427579jpfm0602_2.

Alba, Joseph, John Lynch, Barton Weitz, Chris Janiszewski, Richard Lutz, Alan Sawyer, and Stacy Wood. 1997. Interactive home shopping: Consumer, retailer, and manufacturer incentives to participate in electronic marketplaces. Journal of Marketing 61 (3): 38-53. https://doi.org/10.2307/ 1251788.

Aljukhadar, Muhammad, Sylvain Senecal, and Charles-Etienne Daoust. 2012. Using recommendation agents to cope with information overload. International Journal of Electronic Commerce 17 (2): 41-70. https://doi.org/10.2753/JEC1086-4415170202.

Allen, D.K., and M. Shoard. 2005. Spreading the load: Mobile information and communications technologies and their effect on information overload. Information Research 10 (2): 1-13.

Amit, Adi, and Lilach Sagiv. 2013. The role of epistemic motivation in individuals' response to decision complexity. Organizational Behavior and Human Decision Processes 121 (1): 104-117. https://doi. org/10.1016/j.obhdp.2013.01.003.

Anderson, Matthew J. 1988. A comparative analysis of information search and evaluation behavior of professional and non-professional financial analysts. Accounting, Organizations and Society 13 (5): 431-446. https://doi.org/10.1016/0361-3682(88)90015-3.

Anderson, Simon P., and André de Palma. 2012. Competition for attention in the information (overload) age. The Rand Journal of Economics 43 (1): 1-25. https://doi.org/10.1111/j.1756-2171.2011.00155. $\mathrm{x}$.

Ariely, Dan. 2000. Controlling the information flow: Effects on consumers' decision making and preferences. Journal of Consumer Research 27 (2): 233-248. https://doi.org/10.1086/314322.

Awasthi, Vidya, and Jamie Pratt. 1990. The effects of monetary incentives on effort and decision performance: The role of cognitive characteristics. The Accounting Review 65 (4): 797-811.

Bailey, N. 1975. The mathematical theory of infectious diseases and its applications. London: Griffin.

Baldacchino, C., C. Armistead, and D. Parker. 2002. Information overload: It's time to face the problem. Management Services 46 (1): 18-19.

Bawden, David. 2001. Information overload. Library and Information Briefings 92 (1): 1-15.

Bawden, David, and Lyn Robinson. 2009. The dark side of information: Overload, anxiety and other paradoxes and pathologies. Journal of Information Science 35 (2): 180-191.

Benselin, J.C., and G. Ragsdell. 2016. Information overload: The differences that age makes. Journal of Librarianship and Information Science 48 (3): 284-297. https://doi.org/10.1177/ 0961000614566341.

Berghel, Hal. 1997. Cyberspace 2000: Dealing with information overload. Communications of the ACM 40 (2): 19-24. https://doi.org/10.1145/253671.253680.

Berlo, D. K. 1960. The process of communication. New York: Rinehart \& Winston.

Bettis-Outland, Harriette. 2012. Decision-making's impact on organizational learning and information overload. Journal of Business Research 65 (6): 814-820. https://doi.org/10.1016/j.jbusres.2010.12. 021.

Bettman, James R., and C.W. Park. 1980. Effects of prior knowledge and experience and phase of the choice process on consumer decision processes: A protocol analysis. Journal of Consumer Research 7 (3): 234-248. https://doi.org/10.1086/208812.

Biernacki, P., and D. Waldorf. 1981. Snowball sampling: Problems and techniques of chain referral sampling. Sociological Methods and Research 10 (2): 141-163.

Birnberg, Jacob G., Joan Luft, and Michael D. Shields. 2008. Psychology theory in management accounting research. In Handbook of management accounting research, vol. 1, ed. Christopher S. Chapman, 113-135. Amsterdam: Elsevier.

Blair, Ann. 2012. Information overload's 2,300-year-old history: Harvard business review online resources. http://blogs.hbr.org/cs/2011/03/information_overloads_2300-yea.html. Accessed 28 Feb 2017.

Borkovich, D.J., and R. Morris. 2012. When corporations collide: Information overload. Issues in Information Systems 13 (2): 269-284.

Bouwman, M., P. Frishkoff, and P. Frishkoff. 1993. The relevance of GAAP-based information: A case study exploring some uses and limitations. Accounting Horizons 9 (1): 22-47.

Braun-LaTour, Kathryn A., Nancy M. Puccinelli, and Fred W. Mast. 2007. Mood, information congruency, and overload. Journal of Business Research 60 (11): 1109-1116. https://doi.org/10. 1016/j.jbusres.2007.04.003. 
Broadbent, D. 1958. Perception and communication. London: Pergamon Press.

Bstieler, L. 2006. Trust formation in collaborative new product development. Journal of Product Innovation Management 23 (1): 56-72.

Bucher, Eliane, Christian Fieseler, and Anne Suphan. 2013. The stress potential of social media in the workplace. Information, Communication and Society 16 (10): 1639-1667. https://doi.org/10.1080/ 1369118X.2012.710245.

Burton-Jones, Andrew, and Detmar W. Straub. 2006. Reconceptualizing system usage: An approach and empirical test. Information Systems Research 17 (3): 228-246. https://doi.org/10.1287/isre.1060. 0096.

Butters, Gerard R. 1977. Equilibrium distributions of sales and advertising prices. The Review of Economic Studies 44 (3): 465.

Caniëls, Marjolein C.J., and Ralph J.J.M. Bakens. 2012. The effects of project management information systems on decision making in a multi project environment. International Journal of Project Management 30 (2): 162-175. https://doi.org/10.1016/j.ijproman.2011.05.005.

Cartwright, Jennifer, Sanji de Sylva, Matt Glasgow, Renee Rivard, and Jeremy Whiting. 2002. Inaccessible information is useless information: addressing the knowledge gap. The Journal of medical practice management MPM 18 (1): 36-41.

Case, Donald O., James E. Andrews, J.D. Johnson, and Suzanne L. Allard. 2005. Avoiding versus seeking: The relationship of information seeking to avoidance, blunting, coping, dissonance, and related concepts. Journal of the Medical Library Association 93 (3): 353-362.

Casey, C.J. 1980. Variation in accounting information load: The effect on loan officers' predictions of bankruptcy. The Accounting Review 55 (1): 36-49.

Chan, S.Y. 2001. The use of graphs as decision aids in relation to information overload and managerial decision quality. Journal of Information Science 27 (6): 417-425. https://doi.org/10.1177/ 016555150102700607.

Chan, Yiu M., and Hong Huang. 2013. Weight management information overload challenges in 2007 HINTS: Socioeconomic, health status and behaviors correlates. Journal of Consumer Health On the Internet 17 (2): 151-167. https://doi.org/10.1080/15398285.2013.780540.

Chen, Chien C., Shun-Yuan Shih, and Meng Lee. 2016. Who should you follow? Combining learning to rank with social influence for informative friend recommendation. Decision Support Systems 90: 33-45. https://doi.org/10.1016/j.dss.2016.06.017.

Chen, Min. 2018. Improving website structure through reducing information overload. Decision Support Systems. https://doi.org/10.1016/j.dss.2018.03.009.

Chen, Wenhong, and Kye-Hyoung Lee. 2013. Sharing, liking, commenting, and distressed? The pathway between Facebook interaction and psychological distress. Cyberpsychology, behavior and social networking 16 (10): 728-734. https://doi.org/10.1089/cyber.2012.0272.

Chen, Yu-Chen, Rong-An Shang, and Chen-Yu. Kao. 2009. The effects of information overload on consumers' subjective state towards buying decision in the internet shopping environment. Electronic Commerce Research and Applications 8 (1): 48-58. https://doi.org/10.1016/j.elerap. 2008.09.001.

Chewning, Eugene G., and Adrian Harrell. 1990. The effect of information load on decision makers' cue utilization levels and decision quality in a financial distress decision task. Accounting, Organizations and Society 15 (6): 527-542.

Cole, J.R., and S. Cole. 1972. The Ortega hypothesis: Citation analysis suggests that only a few scientists contribute to scientific progress. Science (New York, N.Y.) 178 (4059): 368-375. https://doi.org/10. 1126/science.178.4059.368.

Conlon, E.J., and J.M. Parks. 1987. Information requests in the context of escalation. Journal of Applied Psychology 72 (3): 344-350.

Cook, G.J. 1993. An empirical investigation of information search strategies with implications for decision support system design. Decision Sciences 24 (4): 683-698.

Cukrowski, Jacek, and Andrzej Baniak. 1999. Organizational restructuring in response to changes in information-processing technology. Review of Economic Design 4 (4): 295-305. https://doi.org/10. $1007 / \mathrm{s} 100580050039$.

D’Arcy, John, Ashish Gupta, Monideepa Tarafdar, and Ofir Turel. 2014. Reflecting on the "dark side" of information technology use. Communications of the ACM 35 (5): 109-118.

Davis, J.G., and S. Ganeshan. 2009. Aversion to loss and information overload-an experimental investigation. ICIS Proceedings 30 (11): 1-14. 
Dean, Derek, and Caroline Webb. 2011. Recovering from information overload. McKinsey Quarterly 11 (1): 80-88.

Denham, S. 2015. Auditory sensing systems: Overview. In Encyclopedia of computational neuroscience, ed. Dieter Jaeger and Ranu Jung, 1-3. New York: Springer New York.

DeShazo, J.R., and German Fermo. 2002. Designing choice sets for stated preference methods: the effects of complexity on choice consistency. Journal of Environmental Economics and Management 44 (1):123-143.

Ding, S., and P. Beaulieu. 2011. The role of financial incentives in balanced scorecard based performance evaluations: Correcting mood congruency biases. Journal of Accounting Research 49: 1223-1247.

Doll, William J., and Gholamreza Torkzadeh. 1988. The measurement of end-user computing satisfaction. MIS Quarterly 12 (2): 258-274. https://doi.org/10.2307/248851.

Dong, John Q., and Jork Netten. 2017. Information technology and external search in the open innovation age: New findings from Germany. Technological Forecasting and Social Change 120: 223-231. https://doi.org/10.1016/j.techfore.2016.12.021.

Driver, M.J., and S. Streufert. 1969. Integrative complexity: An approach to individuals and groups as information processing systems. Administrative Science Quarterly 14 (2): 272-285.

Driver, Michael J., Kenneth R. Brousseau, and Phillip L. Hunsaker. 1990. The dynamic decision maker, 1st ed. Lincoln: iUniverse.

Earle, Timothy C. 2010. Trust in risk management: A model-based review of empirical research. Risk analysis an official publication of the Society for Risk Analysis 30 (4): 541-574. https://doi.org/10. 1111/j.1539-6924.2010.01398.x.

Edmunds, A., and A. Morris. 2000. The problem of information overload in business organizations: A review on the literature. International Journal of Information Management 20 (1): 17-28.

Eppler, M.J., and J. Mengis. 2004. The concept of information overload: A review of literature from organization science, accounting, marketing, MIS and related disciplines. The Information Society 20 (5): 325-344.

Farhoomand, Ali F., and Don H. Drury. 2002. Managerial information overload. Communications of the ACM 45 (10): 127-131. https://doi.org/10.1145/570907.570909.

Feather, J. 1988. The information society: A study of continuity and change. London: Library Association. Festinger, L. 1954. A theory of social comparison. Human Relations 7 (1): 117-140.

Fink, Lior, Liron Rosenfeld, and Gilad Ravid. 2018. Longer online reviews are not necessarily better. International Journal of Information Management 39: 30-37. https://doi.org/10.1016/j.ijinfomgt. 2017.11.002.

Forgas, Joseph P. 1995. Mood and judgment: The affect infusion model (AIM). Psychological Bulletin 117 (1): 39-66. https://doi.org/10.1037/0033-2909.117.1.39.

Forgas, Joseph P., and Jennifer M. George. 2001. Affective influences on judgments and behavior in organizations: an information processing perspective. Organizational Behavior and Human Decision Processes 86 (1): 3-34.

Foster, Allen. 2004. A nonlinear model of information-seeking behavior. Journal of the American Society for Information Science and Technology 55 (3): 228-237. https://doi.org/10.1002/asi.10359.

Gao, Jie, Cheng Zhang, Ke Wang, and Sulin Ba. 2012. Understanding online purchase decision making: The effects of unconscious thought, information quality, and information quantity. Decision Support Systems 53 (4): 772-781. https://doi.org/10.1016/j.dss.2012.05.011.

Gao, Wei, Zhaopeng Liu, Qingqing Guo, and Xue Li. 2018. The dark side of ubiquitous connectivity in smartphone-based SNS: An integrated model from information perspective. Computers in Human Behavior 84: 185-193. https://doi.org/10.1016/j.chb.2018.02.023.

Gottschalk, Sabrina A., and Alexander Mafael. 2017. Cutting through the online review jungleinvestigating selective eWOM processing. Journal of Interactive Marketing 37: 89-104. https://doi. $\operatorname{org} / 10.1016 /$ j.intmar.2016.06.001.

Granovetter, Mark. 1983. The strength of weak ties: a network theory revisited. Sociological Theory 1: 201-233. https://doi.org/10.2307/202051.

Greifeneder, Rainer, Benjamin Scheibehenne, and Nina Kleber. 2010. Less may be more when choosing is difficult: choice complexity and too much choice. Acta Psychologica 133 (1): 45-50. https://doi. org/10.1016/j.actpsy.2009.08.005.

Greiling, D., and K. Spraul. 2010. Accountability and the challenges of information disclosure. Public Administration Quarterly 34 (3): 338-377.

Grise, M. and R. B. Gallupe. 1999/2000. Information overload: Addressing the productivity paradox in face-to-face electronic meetings. Journal of Management Information Systems 16(3):157-185. 
Gupta, Ashish, Han Li, and Ramesh Sharda. 2013. Should I send this message? Understanding the impact of interruptions, social hierarchy and perceived task complexity on user performance and perceived workload. Decision Support Systems 55 (1): 135-145. https://doi.org/10.1016/j.dss.2012.12.035.

Hadfi, Rafik, and Takayuki Ito. 2013. Uncertainty of processes with high-information load. Procedia Social and Behavioral Sciences 97: 612-619.

Hahn, M., R. Lawson, and Y.G. Lee. 1992. The effects of time pressure and information load on decision quality. Psychology and Marketing 9 (5): 365-378.

Hair, Joseph F., Arthur H. Money, Phillip Samouel, and Mike Page. 2007. Research methods for business. Chichester: Wiley.

Halford, G. S., W. H. Wilson, and S. Phillips. 1998. Processing capacity defined by relational complexity. Implications for comparative, developmental, and cognitive psychology. Behavioral and Brain Sciences 21 (6): 803-831 . https://doi.org/10.1017/S0140525X98001769.

Hall, Amanda, and Graham Walton. 2004. Information overload within the health care system: A literature review. Health Information and Libraries Journal 21 (2): 102-108. https://doi.org/10. 1111/j.1471-1842.2004.00506.x.

Hallowell, E.M. 2005. Overloaded circuits: Why smart people underperform. Harvard Business Review 83 (1): 54-62.

Hargittai, Eszter, W.R. Neuman, and Olivia Curry. 2012. Taming the information tide: Perceptions of information overload in the american home. The Information Society 28 (3): 161-173. https://doi. org/10.1080/01972243.2012.669450.

Hemp, Paul. 2009. Death by information overload. Harvard Business Review 87 (9): 82-89.

Hensher, David A. 2006. How do respondents process stated choice experiments? Attribute consideration under varying information load. Journal of Applied Econometrics 21 (6): 861-878. https://doi.org/ 10.1002/jae.877.

Herbig, P.A., and H. Kramer. 1994. The effect of information overload on the innovation choice ürocess. Journal of Consumer Marketing 11 (1): 45-54.

Herther, Nancy K. 1998. Push and the politics of the Internet. The Electronic Library 16 (2): 109-116. https://doi.org/10.1108/eb045624.

Hilary, G., and L. Menzly. 2006. Does past success lead analysts to become overconfident? Management Science 52: 489-500.

Hilton, Denis J. 2010. The psychology of financial decision-making: Applications to trading, dealing, and investment analysis. Journal of Psychology and Financial Markets 2 (1): 37-53. https://doi.org/10. 1207/S15327760JPFM0201_4.

Hiltz, S., and M. Turoff. 1985. Structuring computer-mediated communication systems to avoid information overload. CACM 28 (7): 680-689.

Hofstede, Geert H., and Gert Jan Hofstede. 2005. Cultures and organizations: software of the mind, 2nd ed. New York: McGraw-Hill.

Holton, Avery E., and Hsiang I. Chyi. 2012. News and the overloaded consumer: Factors influencing information overload among news consumers. Cyberpsychology, Behavior and Social Networking 15 (11): 619-624. https://doi.org/10.1089/cyber.2011.0610.

Hsu, Chien-Lung, and Yi-Chuan Liao. 2014. Exploring the linkages between perceived information accessibility and microblog stickiness: The moderating role of a sense of community. Information and Management 51 (7): 833-844. https://doi.org/10.1016/j.im.2014.08.005.

$\mathrm{Hu}$, Hao, and Vincent S. Lai. 2013. Cognitive-based evaluation of consumption fads: An analytical approach. Decision Support Systems 56: 83-91. https://doi.org/10.1016/j.dss.2013.05.001.

Huber, George P. 1991. Organizational learning: the contributing processes and the literatures. Organization Science 2 (1):88-115.

Hult, G.T.M., D.J. Ketchen, and S.F. Slater. 2004. Information processing, knowledge development, and strategic supply chain performance. Academy of Management Journal 47 (2): 241-253. https://doi. org/10.2307/20159575.

Hunter, Gary L., and Daniel J. Goebel. 2013. Salespersons' information overload: Scale development, validation, and its relationship to salesperson job satisfaction and performance. Journal of Personal Selling and Sales Management 28 (1): 21-35. https://doi.org/10.2753/PSS0885-3134280102.

Hutter, Katja, Julia Hautz, Severin Dennhardt, and Johann Füller. 2013. The impact of user interactions in social media on brand awareness and purchase intention: The case of MINI on Facebook. Journal of Product and Brand Management 22 (5/6): 342-351. https://doi.org/10.1108/JPBM-05-2013-0299. 
Hwang, Mark I., and Jerry W. Lin. 1999. Information dimension, information overload and decision quality. Journal of Information Science 25 (3): 213-218. https://doi.org/10.1177/ 016555159902500305 .

Iselin, E.R. 1988. The effects of information load and information diversity on decision quality in a structured decision task. Accounting, Organizations and Society 13 (2): 147-164.

Jackson, Thomas W., and Pourya Farzaneh. 2012. Theory-based model of factors affecting information overload. International Journal of Information Management 32 (6): 523-532. https://doi.org/10. 1016/j.ijinfomgt.2012.04.006.

Jacoby, J. 1977. Information load and decision quality: Some contested issues. Journal of Marketing Research 14 (4): 569-573.

Jacoby, J., D. Speller, and C. Kohn. 1974. Brand choice behavior as a function of information load. Journal of Marketing Research 11 (1): 63-69.

Jacoby, Jacob. 1984. Perspectives on information overload. Journal of Consumer Research 10 (4): 432-436. https://doi.org/10.1086/208981.

Johansson, Björn, Bo Andersson, and Nicklas Holmberg (eds.). 2014. Perspectives in business informatics research: 13th International Conference, BIR 2014, Lund, Sweden, September 22-24, 2014. Proceedings. Cham: Springer International Publishing.

Jones, Quentin, Gilad Ravid, and Sheizaf Rafaeli. 2004. Information overload and the message dynamics of online interaction spaces: A theoretical model and empirical exploration. Information Systems Research 15 (2): 194-210. https://doi.org/10.1287/isre.1040.0023.

Kahneman, Daniel. 2011. Thinking, fast and slow. London: Lane.

Karr-Wisniewski, Pamela, and Ying Lu. 2010. When more is too much: Operationalizing technology overload and exploring its impact on knowledge worker productivity. Computers in Human Behavior 26 (5): 1061-1072. https://doi.org/10.1016/j.chb.2010.03.008.

Keller, Kevin L., and Richard Staelin. 1987. Effects of quality and quantity of information on decision effectiveness. Journal of Consumer Research 14 (2): 200-213. https://doi.org/10.1086/209106.

Kelly, G. A. 1955. The psychology of personal constructs. New York: W.W. Norton \& Co. Inc.

Ketron, Seth, Nancy Spears, and Bo Dai. 2016. Overcoming information overload in retail environments: Imagination and sales promotion in a wine context. Journal of Retailing and Consumer Services 33: 23-32. https://doi.org/10.1016/j.jretconser.2016.07.017.

Kim, Dongmin, and Izak Benbasat. 2009. Trust-assuring arguments in B2C E-commerce: Impact of content, source, and price on trust. Journal of Management Information Systems 26 (3): 175.

Klausegger, Claudia, Rudolf R. Sinkovics, and Huan Zou. 2007. Information overload: A cross-national investigation of influence factors and effects. Marketing Intelligence and Planning 25 (7): 691-718. https://doi.org/10.1108/02634500710834179.

Kock, Ned. 2000. Information overload and worker performance: A process-centered view. Knowledge and Process Management 7 (4): 256-264. https://doi.org/10.1002/1099-1441(200010/12)7:4<256: AID-KPM79>3.0.CO;2-U.

Kolfschoten, Gwendolyn L., and Frances M.T. Brazier. 2013. Cognitive load in collaboration: Convergence. Group Decision and Negotiation 22 (5): 975-996. https://doi.org/10.1007/s10726012-9322-6.

Korhonen, Pekka J., Pekka Malo, Tommi Pajala, Niklas Ravaja, Outi Somervuori, and Jyrki Wallenius. 2018. Context matters: The impact of product type, emotional attachment and information overload on choice quality. European Journal of Operational Research 264 (1): 270-279. https://doi.org/10. 1016/j.ejor.2017.06.060.

Koroleva, K. and A.J. Bolufe-Röhler. 2012. Reducing information overload: Design and evaluation of filtering and ranking algorithms for social networking sites. In ECIS Proceedings, 12.

Koroleva, Ksenia, and Gerald C. Kane. 2016. Relational affordances of information processing on Facebook. Information and Management. https://doi.org/10.1016/j.im.2016.11.007.

Lankton, Nancy K., Cheri Speier, and E.V. Wilson. 2012. Internet-based knowledge acquisition: Task complexity and performance. Decision Support Systems 53 (1): 55-65. https://doi.org/10.1016/j.dss. 2011.12.004.

Lau, R., A.M.T. Hofstede, and P.D. Bruza. 2001. Belief revision for adaptive information filtering agents. International Journal of Cooperative Information Systems 10 (01/02): 57-79. https://doi.org/10. 1142/S0218843001000230.

Ledzińska, Maria, and Sławomir Postek. 2017. From metaphorical information overflow and overload to real stress: Theoretical background, empirical findings, and applications. European Management Journal 35 (6): 785-793. https://doi.org/10.1016/j.emj.2017.07.002. 
Lee, Ae R., Soo-Min Son, and Kyung K. Kim. 2016. Information and communication technology overload and social networking service fatigue: A stress perspective. Computers in Human Behavior 55 (A): 51-61. https://doi.org/10.1016/j.chb.2015.08.011.

Lee, Byung-Kwan, and Wei-Na Lee. 2004. The effect of information overload on consumer choice quality in an on-line environment. Psychology and Marketing 21 (3): 159-183. https://doi.org/10. 1002/mar.20000.

Lee, Sun K., Nathan J. Lindsey, and Kyun S. Kim. 2017. The effects of news consumption via social media and news information overload on perceptions of journalistic norms and practices. Computers in Human Behavior 75: 254-263. https://doi.org/10.1016/j.chb.2017.05.007.

Lev, B., and S. Thiagarajan. 1993. Fundamental information analysis. Journal of Accounting Research 31 (2): 190-215.

Levitin, Daniel J. 2014. The organized mind: Thinking straight in the age of information overload. New York: Penguin.

Lewis, D. 1996. Dying for information?. London: Reuters Business Information.

Li, Chia-Ying. 2016. Why do Online consumers experience information overload? An extension of communication theory. Journal of Information Science 8 (1): 1-17. https://doi.org/10.1177/ 0165551516670096.

Li, Pei, and Yunchuan Sun. 2014. Modeling and performance analysis of information diffusion under information overload in Facebook-like social networks. International Journal of Communication Systems 27 (9): 1268-1288. https://doi.org/10.1002/dac.2774.

Liang, Ting-Peng, Hung-Jen Lai, and Ku Yi-Cheng. 2007. Personalized content recommendation and user satisfaction: Theoretical synthesis and empirical findings. Journal of Management Information Systems 23 (3): 45-70. https://doi.org/10.2753/MIS0742-1222230303.

Lin, Chang-Chun. 2006. Optimal web site reorganization considering information overload and search depth. European Journal of Operational Research 173 (3): 839-848. https://doi.org/10.1016/j.ejor. 2005.05.029.

Lindblom, C. E. 1959. The science of "muddling through". Public Administration Review 19 (2): 79. https://doi.org/10.2307/973677.

Lipowski, Z.J. 1970. The conflict of buridan's ass or some dilemmas of affluence: The theory of attractive stimulus overload. The American journal of psychiatry 127 (3): 273-279. https://doi.org/10.1176/ ajp.127.3.273.

Lohr, S. 2007. Is information overload a $\$ 650$ billion drag on the economy. New York Times 2, 20 Dec 2007.

Luedicke, Marius K., Katharina C. Husemann, Santi Furnari, and Florian Ladstaetter. 2017. Radically open strategizing: How the premium cola collective takes open strategy to the extreme. Long Range Planning 50 (3): 371-384. https://doi.org/10.1016/j.lrp.2016.07.001.

Luft, Joan, and Michael D. Shields. 2003. Mapping management accounting: Graphics and guidelines for theory-consistent empirical research. Accounting, Organizations and Society 28 (2-3): 169-249. https://doi.org/10.1016/S0361-3682(02)00026-0.

Lurie, Nicholas H. 2004. Decision making in information-rich environments: The role of information structure. Journal of Consumer Research 30 (4): 473-486. https://doi.org/10.1086/380283.

Maes, P. 1994. Agents that reduce work and information overload. Communications of the ACM 37 (7): $30-40$.

Malhotra, N.K. 1984. Reflections on the information overload paradigm in consumer decision making. Journal of Consumer Research 10 (3): 436-441.

Malhotra, N.K., A.K. Jain, and S.W. Lagakos. 1982. The information overload controversy: An alternate viewpoint. Journal of Marketing Research 46 (1): 27-37.

Maslach, Christina, and Susan E. Jackson. 1981. The measurement of experienced burnout. Journal of Organizational Behavior 2 (2): 99-113.

McCoy, Scott, Andrea Everard, Peter Polak, and Dennis F. Galletta. 2007. The effects of online advertising. Communications of the ACM 50 (3): 84-88. https://doi.org/10.1145/1226736.1226740.

Meadow, C.T., and W. Yuan. 1997. Measuring the impact of information: Defining the concepts. Information Processing and Management 33 (6): 701-702.

Melinat, Peter, Tolja Kreuzkam, and Dirk Stamer. 2014. Information overload: A systematic literature review. In Perspectives in business informatics research: 13th international conference, BIR 2014, Lund, Sweden, September 22-24, 2014. Proceedings, vol. 194, ed. Björn Johansson, Bo Andersson, and Nicklas Holmberg, 72-86. Cham: Springer International Publishing. 
Messner, Claude, and Michaela Wänke. 2011. Unconscious information processing reduces information overload and increases product satisfaction. Journal of Consumer Psychology 21 (1): 9-13. https:// doi.org/10.1016/j.jcps.2010.09.010.

Meyer, J. 1998. Information overload in marketing management. Marketing Intelligence and Planning 16 (2): 200-209.

Miller, George A. 1956. The magical number seven, plus or minus two: Some limits on our capacity for processing information. Psychological Review 63 (1): 81-97.

Misra, Shalini, and Daniel Stokols. 2012. Psychological and health outcomes of perceived information overload. Environment and Behavior 44 (6): 737-759. https://doi.org/10.1177/0013916511404408.

Misuraca, Raffaella, and Ursina Teuscher. 2013. Time flies when you maximize-maximizers and satisficers perceive time differently when making decisions. Acta Psychologica 143 (2): 176-180. https://doi.org/10.1016/j.actpsy.2013.03.004.

Moore, Bert S., and A.M. Isen. 1990. Affect and social behavior. In Affect and social behavior, ed. Bert S. Moore and A.M. Isen, 1-21. Cambridge: Cambridge University Press.

Moore, Jo E. 2000. One road to turnover: An examination of work exhaustion in technology professionals. MIS Quarterly 24 (1): 141-168. https://doi.org/10.2307/3250982.

Newell, A., and H. Simon. 1972. Human problem solving. Upper Saddle River: Prentice Hall.

O'Reilly, C.A. 1980. Individuals and information overload in organizations: Is more necessarily better? Academy of Management Journal 23 (4): 684-696.

Oizumi, Masafumi, Larissa Albantakis, and Giulio Tononi. 2014. From the phenomenology to the mechanisms of consciousness: Integrated information theory 3.0. PLoS Computational Biology 10 (5): e1003588. https://doi.org/10.1371/journal.pcbi.1003588.

Okike, Chikezie, and Kiran J. Fernandes. 2012. Impact of information use architecture on load and usability. Information Processing and Management 48 (5): 995-1016. https://doi.org/10.1016/j.ipm. 2012.04.003.

Oldroyd, J.B., and S.S. Morris. 2012. Catching falling stars: A human resource response to social capital's detrimental effect of information overload on star employees. Academy of Management Review 37 (3): 396-418. https://doi.org/10.5465/amr.2010.0403.

Oluwadare, Emmanuel, and Martin Samy. 2015. The relevance of critical accounting theory (CAT) to effectiveness of public financial accountability in emerging economies. Canadian Social Science 11 (9): 20-25.

Osburg, Victoria-Sophie, Shanna Appelhanz, Waldemar Toporowski, and Matthias Schumann. 2016. An empirical investigation of wood product information valued by young consumers. Journal of Cleaner Production 110: 170-179. https://doi.org/10.1016/j.jclepro.2015.01.068.

Owen, R.S. 1992. Clarifying the simple assumption of the information load paradigm. Advances in Consumer Research 19 (4): 770-776.

Paul, Souren, and Derek L. Nazareth. 2010. Input information complexity, perceived time pressure, and information processing in GSS-based work groups: An experimental investigation using a decision schema to alleviate information overload conditions. Decision Support Systems 49 (1): 31-40. https://doi.org/10.1016/j.dss.2009.12.007.

Payne, John W. 1976. Task complexity and contingent processing in decision making: An information search and protocol analysis. Organizational Behavior and Human Performance 16 (2): 366-387. https://doi.org/10.1016/0030-5073(76)90022-2.

Payne, John W., James R. Bettman, and Eric J. Johnson. 1992. Behavioral decision research: a constructive processing perspective. Annual Review of Psychology 43 (1): 87-131.

Pennington, R., and B. Tuttle. 2007. The effects of information overload on software project risk assessment. Decision Sciences 38 (3): 489-526.

Pennington, Robin R., and Andrea S. Kelton. 2016. How much is Enough? An investigation of nonprofessional investors information search and stopping rule use. International Journal of Accounting Information Systems 21: 47-62. https://doi.org/10.1016/j.accinf.2016.04.003.

Plotnick, L., M. Turoff, and G. van den Eede. 2009. Reexamining threat rigidity: Implications for design. In 2009 42nd Hawaii international conference on system sciences, Waikoloa, Hawaii, USA, 1-10.

Plumlee, Marlene A. 2003. The effect of information complexity on analysts' use of that information. The Accounting Review 78 (1): 275-296. https://doi.org/10.2308/accr.2003.78.1.275.

Radner, Roy. 1993. The organization of decentralized information processing. Econometrica 61 (5): 1109-1146. https://doi.org/10.2307/2951495.

Ramnath, Sundaresh, Steve Rock, and Philip Shane. 2008. The financial analyst forecasting literature: A taxonomy with suggestions for further research. International Journal of Forecasting 24 (1): 34-75. 
Reutskaja, Elena, and Robin M. Hogarth. 2009. Satisfaction in choice as a function of the number of alternatives: When "goods satiate”. Psychology and Marketing 26 (3): 197-203. https://doi.org/10. 1002/mar.20268.

Rodríguez-Molina, M.A., D.M. Frías-Jamilena, and J.A. Castañeda-García. 2015. The contribution of website design to the generation of tourist destination image: The moderating effect of involvement. Tourism Management 47: 303-317. https://doi.org/10.1016/j.tourman.2014.10.001.

Roetzel, P.G. 2014. The impact of creativity and information load on escalation of commitment. In ECIS Proceedings.

Roetzel, P.G., D. Fischer, and B. Pedell. 2015. The Effect of Information Load on Escalation of Commitment. In CAAA annual conference (Canadian Academic Accounting Association) Proceedings.

Roetzel, Peter G. and Christian Lohmann. 2014. The Influence of the perception of fairness on innovation idea value and knowledge sharing behavior in innovation idea networks. In ECIS Proceedings.

Rogers, E. M., and R. Agarwala-Rogers. 1975. Organizational communication. In Communication and behavior, eds. G. J. Hanneman, W. J. McEwen, and D. K. Berlo, 151-198. Reading, MA: AddisonWesley.

Rogers, R., and J. Grant. 1997. Content analysis of information cited in reports of sell-side financial analysts. Journal of Financial Statement Analysis 3 (1): 17-30.

Saparova, Dinara, Francis Kibaru, and Josipa Bašić. 2013. Use of widgets as information management tools in online shared spaces. International Journal of Information Management 33 (2): 401-407. https://doi.org/10.1016/j.ijinfomgt.2012.12.001.

Sasaki, Yuichi, Daisuke Kawai, and Satoshi Kitamura. 2015. The anatomy of tweet overload: how number of tweets received, number of friends, and egocentric network density affect perceived information overload. Telematics and Informatics 32 (4): 853-861. https://doi.org/10.1016/j.tele. 2015.04.008.

Saunders, Carol, Martin Wiener, Sabrina Klett, and Sebastian Sprenger. 2017. The impact of mental representations on ICT-related overload in the use of mobile phones. Journal of Management Information Systems 34 (3): 803-825. https://doi.org/10.1080/07421222.2017.1373010.

Savolainen, Reijo. 2007. Filtering and withdrawing: Strategies for coping with information overload in everyday contexts. Journal of Information Science 33 (5): 611-621. https://doi.org/10.1177/ 0165551506077418.

Schaltegger, Stefan, Delphine Gibassier, and Dimitar Zvezdov. 2013. Is environmental management accounting a discipline? A bibliometric literature review. Meditari Accountancy Research 21 (1): 4-31. https://doi.org/10.1108/MEDAR-12-2012-0039.

Scheibehenne, Benjamin, Rainer Greifeneder, and Peter M. Todd. 2010. Can there ever be too many options? A meta-analytic review of choice overload. Journal of Consumer Research 37 (3): 409-425. https://doi.org/10.1086/651235.

Schick, Allen G., Lawrence A. Gordon, and Susan Haka. 1990. Information overload: A temporal approach. Accounting, Organizations and Society 15 (3): 199-220. https://doi.org/10.1016/03613682(90)90005-F.

Schneider, S.C. 1987. Information overload: Causes and consequences. Human Systems Management 7 (1): $143-153$.

Schroder, H., M.J. Driver, and S. Streufert. 1967. Human information processing. New York: Holt, Rinehart and Winston.

Schuff, David, Ozgur Turetken, and John D’Arcy. 2006. A multi-attribute, multi-weight clustering approach to managing "e-mail overload”. Decision Support Systems 42 (3): 1350-1365. https://doi. org/10.1016/j.dss.2005.11.003.

Schultze, Thomas, Felix Peiffer, and Stefan Schulz-Hardt. 2012. Biased information processing in the escalation paradigm: Information search and information evaluation as potential mediators of escalating commitment. Journal of Applied Psychology 97 (1): 16-32.

Schultze, Ulrike, and Betty Vandenbosch. 1998. Information overload in a groupware environment: Now you see it, now you don't. Journal of Organizational Computing and Electronic Commerce 8 (2): 127-148. https://doi.org/10.1207/s15327744joce0802_3.

Scott, Judy E. 2005. Post-implementation usability of ERP training manuals: The user's perspective. Information Systems Management 22 (2): 67-77. https://doi.org/10.1201/1078/45099.22.2. 20050301/87279.8.

Shannon, C.E., and W. Weaver. 1959. The mathematical theory of communication. Urbana: University of Illinois. 
Shapiro, C., and H.R. Varian. 2013. Information rules: A strategic guide to the network economy. Boston: Harvard Business Press.

Sharma, Aseem, Krishna Jagannathan, and Lav R. Varshney. 2014. Information overload and human priority queuing. In IEEE international symposium on information theory (ISIT), 2014: June 29, 2014-July 4, 2014, Honolulu, Hawaii, USA. 2014 IEEE International Symposium on Information Theory (ISIT), Honolulu, HI, USA, 831-835. Piscataway: IEEE.

Shenk, D. 1997. Data smog: Surviving the information glut. London: Abacus.

Sherer, Pamela D., Timothy P. Shea, and Eric Kristensen. 2003. Online communities of practice: A catalyst for faculty development. Innovative Higher Education 27 (3): 183-194. https://doi.org/10. 1023/A: 1022355226924

Shields, Michael D. 1980. Some effects of information load on search patterns used to analyze performance reports. Accounting, Organizations and Society 5 (4): 429-442.

Shields, Michael D. 1983. Effects of information supply and demand on judgment accuracy: Evidence from corporate managers. The Accounting Review 58 (2): 284-303.

Shrivastav, H., and S.R. Hiltz. 2013. Information overload in technology-based education: A metaanalysis. Americas Conference on Information Systems (AMCIS) 1: 1-10.

Shrivastava, Paul. 1983. A typology of organizational learning systems. Journal of Management Studies 20 (1): 7-28.

Sicilia, Maria, and Salvador Ruiz. 2010. The effects of the amount of information on cognitive responses in online purchasing tasks. Electronic Commerce Research and Applications 9 (2): 183-191. https:// doi.org/10.1016/j.elerap.2009.03.004.

Simnet, Roger. 1996. The effect of information selection, information processing and task complexity on predictive accuracy of auditors. Accounting, Organizations and Society 21 (7-8): 699-719. https:// doi.org/10.1016/0361-3682(96)00006-2.

Simon, H.A. 1971. Designing organizations for an information-rich world. Computers, Communication, and the Public Interest 1: 40-41.

Simon, Herbert A. 1955. A behavioral model of rational choice. Quarterly Journal of Economics 69 (1): 99-118.

Simon, Herbert A., and Allen Newell. 1971. Human problem solving: The state of the theory in 1970. American Psychologist 26 (2): 145-159. https://doi.org/10.1037/h0030806.

Slawson, D.C., A.F. Shaughnessy, and J.H. Bennett. 1994. Becoming a medical information master: Feeling good about not knowing everything. The Journal of family practice 38 (5): 505-513.

Slovic, Paul. 1993. Perceived risk, trust, and democracy. Risk Analysis 13 (6): 675-682. https://doi.org/ 10.1111/j.1539-6924.1993.tb01329.x.

Snowball, D. 1979. Information load and accounting reports: Too much, too little or just right? Cost and Management 1 (5): 22-28.

Snowball, D. 1980. Some effects of accounting expertise and information load: An empirical study. Accounting, Organizations and Society 5 (3): 323-338.

Soucek, Roman, and Klaus Moser. 2010. Coping with information overload in e-mail communication: evaluation of a training intervention. Computers in Human Behavior 26 (6): 1458-1466. https://doi. org/10.1016/j.chb.2010.04.024.

Sparrow, P.R. 1999. Strategy and cognition: understanding the role of management knowledge structures, organizational memory and information overload. Creativity and Innovation Management 8 (2): 140-149.

Speier, C., J. Valacich, and I. Vessey. 1999. Information overload through interruptions: An empirical examination of decision making. Decision Sciences 30 (2): 337-360.

Speier, Cheri, Iris Vessey, and Joseph S. Valacich. 2003. The effects of interruptions, task complexity, and information presentation on computer-supported decision-making performance. Decision Sciences 34 (4): 771-797. https://doi.org/10.1111/j.1540-5414.2003.02292.x.

Spindler, Gerald. 2011. Behavioural finance and investor protection regulations. Journal of Consumer Policy 34 (3): 315-336. https://doi.org/10.1007/s10603-011-9165-6.

Sprinkle, G.B., and M.G. Williamson. 2008. Experimental research in managerial accounting. In Handbook of management accounting research, ed. Christopher S. Chapman, 415-444. Amsterdam: Elsevier.

Staples, D.S., and Jane Webster. 2008. Exploring the effects of trust, task interdependence and virtualness on knowledge sharing in teams. Information Systems Journal 18 (6): 617-640. https://doi.org/10. 1111/j.1365-2575.2007.00244.x.

Stigler, George J. 1961. The economics of information. Journal of Political Economy 69 (3): 213-225. 
Sumecki, David, Maxwell Chipulu, and Udechukwu Ojiako. 2011. E-mail overload: Exploring the moderating role of the perception of e-mail as a 'business critical' tool. International Journal of Information Management 31 (5): 407-414. https://doi.org/10.1016/j.ijinfomgt.2010.12.008.

Summers, John O. 1974. Less information is better? Journal of Marketing Research 11 (4): 467. https:// doi.org/10.2307/3151299.

Swain, M.R., and S.F. Haka. 2000. Effects of information load on capital budgeting decisions. Behavioral Research in Accounting 12 (1): 171-198.

Swar, Bobby, Tahir Hameed, and Iris Reychav. 2017. Information overload, psychological ill-being, and behavioral intention to continue online healthcare information search. Computers in Human Behavior 70: 416-425. https://doi.org/10.1016/j.chb.2016.12.068.

Sweller, J. 1988. Cognitive load during problem solving: Effects on learning. Cognitive Science 12 (4): 257-285.

Sweller, J., R.F. Mawer, and M.R. Ward. 1983. Development of expertise in mathematical problem solving. Journal of Experimental Psychology: General 112: 639-661.

Száva-Kováts, Endre. 2004. The false 'Ortega hypothesis': A literature science case study. Journal of Information Science 30 (6): 496-508. https://doi.org/10.1177/0165551504047823.

Tam, K.Y., and S.Y. Ho. 2006. Understanding the impact of web personalization on user information processing and decision outcomes. MIS Quarterly 30 (4): 865-890.

Tarafdar, Monideepa, Tu Qiang, and T.S. Ragu-Nathan. 2010. Impact of technostress on end-user satisfaction and performance. Journal of Management Information Systems 27 (3): 303-334. https:// doi.org/10.2753/MIS0742-1222270311.

Tushman, M.L., and D.A. Nadler. 1978. Information processing as an integrating concept in organizational design. Academy of Management Review 3 (3): 613-624. https://doi.org/10.5465/ AMR.1978.4305791.

Tuttle, B., and F.G. Burton. 1999. The effects of a modest incentive on information overload in an investment analysis task. Accounting, Organizations and Society 24 (8): 673-687.

Tversky, Amos, and Daniel Kahneman. 1974. Judgment under uncertainty: Heuristics and biases. Science 185 (9): 1124-1131.

United Nations Statistic Division. 2016. GDP and its breakdown at current prices in US Dollars (2015): December 2016. New York: United Nations.

Wang, Kuo-Ching, Shu-Hui Chou, Su Che-Jen, and Hsin-Yi Tsai. 2007. More information, stronger effectiveness? Different group package tour advertising components on web page. Journal of Business Research 60 (4): 382-387. https://doi.org/10.1016/j.jbusres.2006.09.024.

Wang, Qiuzhen, Sa Yang, Manlu Liu, Zike Cao, and Qingguo Ma. 2014. An eye-tracking study of website complexity from cognitive load perspective. Decision Support Systems 62: 1-10. https://doi. org/10.1016/j.dss.2014.02.007.

Ward, C. and V. Ramachandran. 2010. Crowdfunding the next hit: Microfunding online experience goods. In Workshop on Computational Social Science and the Wisdom of Crowds at NIPS 2010, $1-5$.

Webster, J., and R.T. Watson. 2002. Analyzing the past to prepare for the future. MIS Quarterly 26 (2): xiii-xxiii.

Wedell, Douglas H., and Stuart M. Senter. 1997. Looking and weighting in judgment and choice. Organizational Behavior and Human Decision Processes 70 (1): 41-64.

Wei, Kangning, and Jiwat Ram. 2016. Perceived usefulness of podcasting in organizational learning: The role of information characteristics. Computers in Human Behavior 64: 859-870. https://doi.org/10. 1016/j.chb.2016.08.003.

Weick, K. E. 1995. Sensemaking in organisations. Thousand Oaks, CA: Sage.

Wheeler, Patrick, and Vairam Arunachalam. 2009. The effects of multimedia on cognitive aspects of decision-making. International Journal of Accounting Information Systems 10 (2): 97-116. https:// doi.org/10.1016/j.accinf.2008.10.004.

Whelan, Eoin, and Robin Teigland. 2013. Transactive memory systems as a collective filter for mitigating information overload in digitally enabled organizational groups. Information and Organization 23 (3): 177-197. https://doi.org/10.1016/j.infoandorg.2013.06.001.

Wilson, P. 1996. Interdisciplinary research and information overload. Library Trends 45 (2): $192-203$.

Wilson, T.D. 1999. Models in information behaviour research. Journal of Documentation 55 (3): 249-270. https://doi.org/10.1108/EUM0000000007145.

Wilson, T.D. 2001. Information overload: Implications for healthcare services. Health Informatics Journal 7 (2): 112-117. https://doi.org/10.1177/146045820100700210. 
Wu, Ling-Ling, and Jia-Yan Lin. 2006. The quality of consumers' decision-making in the environment of e-commerce. Psychology and Marketing 23 (4): 297-311. https://doi.org/10.1002/mar.20112.

Xiao, B., and I. Benbasat. 2007. E-commerce product recommendation agents: Use, characteristics, and impact. MIS Quarterly 31 (1): 137-209.

Yen, John, Xiaocong Fan, Shuang Sun, Timothy Hanratty, and John Dumer. 2006. Agents with shared mental models for enhancing team decision makings. Decision Support Systems 41 (3): 634-653. https://doi.org/10.1016/j.dss.2004.06.008.

Zeldes, Nathan, David Sward, and Sigal Louchheim. 2007. Infomania: why we can't afford to ignore it any longer. First Monday. https://doi.org/10.5210/fm.v12i8.1973.

Zha, Xianjin, Haijuan Yang, Yalan Yan, Kunfeng Liu, and Chengsong Huang. 2018. Exploring the effect of social media information quality, source credibility and reputation on informational fit-to-task: Moderating role of focused immersion. Computers in Human Behavior 79: 227-237. https://doi.org/ 10.1016/j.chb.2017.10.038.

Zhang, Hong, Ling Zhao, and Sumeet Gupta. 2018. The role of online product recommendations on customer decision making and loyalty in social shopping communities. International Journal of Information Management 38 (1): 150-166. https://doi.org/10.1016/j.ijinfomgt.2017.07.006.

Zhang, Shuwei, Ling Zhao, Lu Yaobin, and Jun Yang. 2016. Do you get tired of socializing? An empirical explanation of discontinuous usage behaviour in social network services. Information and Management 53 (7): 904-914. https://doi.org/10.1016/j.im.2016.03.006.

Zhou, Kevin Z., and Caroline B. Li. 2012. How knowledge affects radical innovation: Knowledge base, market knowledge acquisition, and internal knowledge sharing. Strategic Management Journal 33 (9): 1090-1102. https://doi.org/10.1002/smj.1959.

Publisher's Note Springer Nature remains neutral with regard to jurisdictional claims in published maps and institutional affiliations. 